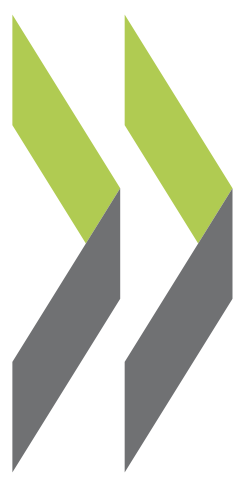

OECD Social, Employment and Migration Working Papers No. 3

\title{
International Movements \\ of the Highly Skilled
}

\section{John Salt}




\section{DIRECTORATE FOR EDUCATION, EMPLOYMENT, LABOUR AND SOCIAL AFFAIRS - INTERNATIONAL MIGRATION UNIT - OCCASIONAL PAPERS N 3 \\ INTERNATIONAL MOVEMENTS OF THE HIGHLY SKILLED}

by John Salt

ORGANISATION FOR ECONOMIC CO-OPERATION AND DEVELOPMENT

Paris

57824

Document complet disponible sur OLIS dans son format d'origine

Complete document available on OLIS in its original format 


\section{OCCASIONAL PAPERS}

The attached report has been prepared by Mr. John Salt," consultant to the Secretariat. Mr. John Salt is a Professor at the University College London (UCL). The report is part of the OECD's activities on foreign labour migration in particular concerning temporary workers.

Copyright, OECD, 1997

This document is published on the responsibility of the Secretary General of the OECD.

Applications for permission to reproduce or translate all or parts of this material should be made to: Head of Publications Service, OECD, 2 rue André-Pascal, 75775 Paris Cedex 16, France

* The assistance of Dr. Khalid Koser in the preparation of this report is gratefully acknowledged. 


\section{SUMMARY}

In recent years there has been a growing recognition of the importance of international recruitment and movement of the highly skilled. Modern industries and services increasingly rely upon the acquisition, deployment and use of human expertise to add value in their operations. When this expertise is not available locally, employers frequently import it from abroad. This takes place in the context of two fundamental and interrelated processes: the development of internal labour markets by employers, on the one hand, and of the institutional framework by governments to facilitate the global interchange of skills, on the other.

The principal flows of highly skilled workers today reflect the global expansion of world trade, the international expansion of trans-national corporations, and the activities of institutions such as governments and recruitment agencies. Although not straightforward, there appears for example to be a positive relationship between flows of skilled labour and flows of investment. Increasingly, the highly skilled have come to move more freely as work permit systems have changed to accommodate the global search for expertise.

There is no agreed concept or definition of the highly skilled. Most commentators assume them to have a tertiary educational qualification or its equivalent, although the skills can also be acquired through experience. The lack of a generally recognised definition is reflected in the problems encountered regarding the recognition of qualifications across countries. What is needed for analytical purposes is a typology which accommodates the diversity of the group, the sub-categories of which may have very different compositions and patterns of mobility. Despite the importance of migration by the highly skilled to the development of the international economy, there are few detailed data on the scale and nature of their migration.

Regarding prospects for the future, the paper projects a general stabilisation in the movements of highlyskilled workers, attributable among other reasons to the greater use of overseas subsidiaries and collaborators and of business service firms, increased use of air travel and the application of new information technologies which render a physical presence less necessary. 


\section{INTERNATIONAL MOVEMENTS OF THE HIGHLY SKILLED}

\section{Introduction}

In recent years there has been a growing recognition of the importance of international recruitment and movement by the highly skilled. Although the literature is not yet very extensive, a number of themes have been developing: migrations associated with the activities of multinational companies; brain drain and return; the emergence of an international skills market; and the migration of students and researchers.

The core of the interest in the migration of the highly skilled is economic. Modern industries and services increasingly rely upon the acquisition, deployment and use of human expertise to add value in their operations. Where this expertise is not available locally, employers frequently search for it abroad. They do this in a number of ways: direct recruitment from the external labour market (ELM); from within their own corporate internal labour markets (ILMs); by acquiring businesses overseas; through partnership agreements or joint ventures; or from specialist firms. Frequently this movement is relatively short-term, and takes the form of a secondment or limited period assignment, perhaps for two or three years only. The consequence is that the economically most developed countries routinely exchange high level skills, while increasingly the less developed world is being brought into skill exchange and "brain drain" networks.

Theories to explain this form of migration have only comparatively recently begun to get to grips with two fundamental and interrelated processes: the organisation of employment and the development of ILMs by employers; and the institutional framework created by governments designed to facilitate the global interchange of skills. One reason for this tardiness has been a reluctance by many migration researchers and officials to accept that such movement is really migration at all, since there is no intention to settle in the destination country. Another reason is that highly skilled migrants tend to be middle class, well paid and "invisible". For the most part, their presence as immigrants rarely gives rise to even the mildest political debate. Finally, there is little statistical information on either the numbers or characteristics of highly skilled migrants, though the size of flows is usually thought to be small and largely insignificant in the context of total movement.

One of the principal aims of this report is to use empirical information to demonstrate how the interaction of the two processes introduced above creates a selective and highly managed flow of skills into a modern economy. Such processes of selection and management are largely instrumental in maintaining a highly dichotomised pattern of labour migration in today's world, the extremes of which are represented by senior executives transferred by large corporations, and low-paid illegal immigrant labourers working in informal economies. 
Attempts to define the highly skilled confront a series of conceptual, definitional, and data problems. This section analyses these in turn, and includes a suggested categorisation of the major types of the highly skilled. It concludes with a brief critique of current data sources.

\section{Basic Concepts}

There is no agreed concept or definition of the highly skilled. It is clear, though that they do not constitute a homogeneous group, although in broad terms they may be described as professional, managerial and technical (PMT) specialists. The group as a whole consists of a series of largely self-contained and noncompeting sub-groups, among whom levels and duration of training are such as to lead to low elasticities of supply.

A review of the literature on the migration of highly skilled people reveals two basic concepts:

- Brain exchange (including brain gain and brain drain). The essence of this multi-faceted concept is that those who move take on a job in the new location broadly commensurate with their skills and qualifications. Brain exchange implies a two-way flow of expertise between origin and destination. Where the net flow is heavily in one direction, the terms "brain gain" or "brain drain" tend to be used. Brain exchanges in some form are characteristic of all economies, and are one component in the complex of flows of goods, information, finance etc. between advanced economies. Although the notion of brain drain was originally addressed to migration from Europe (specifically the UK) to North America in the 1960s, it is now used to describe the net loss of highly skilled labour from Third World countries and, more recently, from East to West in Europe.

- Brain waste. This concept describes the deskilling that occurs when highly skilled workers migrate into forms of employment not requiring the application of the skills and experience applied in the former job. There is abundant evidence of this process, especially where standard of living gradients are steep. This group, however, is not the subject of this report (see Bernstein and Shuval, 1996, for a recent case study).

\section{Potential Measurement}

Most commentary on the highly skilled assumes them to have a tertiary educational qualification or its equivalent. However, many graduates are not in highly skilled jobs; conversely, many whose work is highly skilled are not graduates. The nature of the work performed, and the expertise required, offer further definitional complications because of their rich diversity. Entry into some PMT occupations is related largely to general academic training, to first degree standard. In other cases training is occupation-specific, leading to a diploma or a general occupational entry qualification. The ability to perform in a highly skilled capacity is sometimes linked to previous experience, or to a combination of experience and formal qualification (such as an MBA). After entry, progression may be up a well-structured career ladder without additional formal qualifications or training; or ladders may overlap, necessitating retraining or new qualifications. Some jobs that are rightly deemed to be highly skilled may require little by way of training or experience, relying on natural talent: sportspeople, entertainers, musicians and artists are examples. Many of these are highly mobile internationally, but they are rarely discussed in the migration literature (an exception is Todisco, 1993). 


\section{Recognition of Qualifications}

The nature of the qualifications required, and the location and means of acquiring them, add further to the heterogeneity of the highly skilled. It is important for the mobility of such people that their qualifications receive universal recognition. Over the last 30 years EC/EU directives designed to improve mobility have been adopted for some professions on an occupation by occupation basis: for medical and paramedical occupations, architects and solicitors, for example. But because this is a slow process, the EU has now adopted a more general approach based on the length of time taken to complete a course of study or training. Although this has made it possible from 1991 for the mutual recognition of qualifications, in practice it has had little impact since private enterprise could already freely recruit EC nationals. Evidence from multinational employers in the UK suggests that qualifications present few problems to recruitment and retention of skilled staff, though in some professions, such as the law, difficulties do arise. Firms are able to get round qualification problems in other ways, especially obtaining expertise through business service firms or by collaboration with overseas companies (Salt, 1990).

As the market for the highly skilled becomes even more global, the issue of international recognition of professional qualifications will become more pressing. This is seen in the international exchange of nurses in which the UK is involved. Between 1984/5 and 1990/1 the total inflow of nurses to the UK increased from 2600 to 3400 , while outflow also rose, from 3000 to 8500 (Buchan et al., 1992). Recently the Norwegian Directorate of Labour has decided to recruit 300 doctors per year for the next three years, mainly from Germany, Austria and Finland (Aftenposten, 1997). Most of the exchange is with developed countries, especially Australia, New Zealand, Eire and USA, where recognition of qualifications is less of a problem. While there may be some movement towards harmonisation of qualifications, particularly at a general educational level (such as acknowledgement of the high quality of the degrees of the best universities), coping with the quality of many vocational courses and their resulting qualifications will present more difficulties.

Further definitional problems attend upon those whose work is ancillary to the highly skilled, alongside whom they often work in some symbiotic relationship. They include technicians, linguistic and other specialists, and nurses. Most would agree that they are "skilled", but they serve to emphasise the impossibility of coming up with a firm definition of "highly skilled".

\section{A wide spectrum of the highly skilled}

Few systematic attempts have been made to categorise the highly skilled and their patterns of mobility. Gould (1988) developed a typology of skilled international migration based on the types of movement associated with levels of economic development. A similar approach was proposed by Logan (1992) who emphasised the geographical direction of migration between and within more- and less-developed countries. What is needed, however, is a typology which accommodates the diversity of the group, the sub-categories of which may have very different compositions and patterns of mobility.

The scheme below attempts to identify the most important categories of temporary highly skilled migrants. Although it attempts to distinguish groups that are conceptually different, it is impossible to avoid some overlap between them. For example, several of the types identified may move within employers' ILMs. Although their existence is acknowledged, not all of the types listed below are treated in detail in the body of this paper. Permanent landed immigrants and business travellers are not included, nor are those moving into occupations involving marked deskilling. 
a) Corporate transferees. These people move internationally within the ILMs of large employing organisations. Their moves are for a wide range of reasons, and for varying time periods. Frequently, moves are related to career development and training, but they may also be production, marketing or research specialists. Their moves generally reflect the organisational structure of their employers.

b) Technicians/visiting firemen. These are people whose movements reflect the particular occupational skills they have, and they may occur within the ILMs of trans-national corporations (TNCs). Moves may be related to specific project developments. Moves may be unpredictable, responding to crisis management needs.

c) Professionals, frequently working in the health or educational sectors, and often employed by non-governmental organisations (NGOs). Recruitment is frequently on an individual level, and for fixed term contracts abroad. With some NGOs, employment overseas may become permanent.

d) Project specialists. Their migrations are related to specific overseas projects, often in construction. Moves may technically occur within corporate ILMs, although often they are recruited through the ELM for a limited contractual period.

e) Consultant specialists. Increasingly employing organisations are using specialist consultancies for a range of business services. Locations are worldwide, depending on the clients' organisational structures. Consultancy firms are themselves increasingly transnational in their own organisation.

f) Private career development and training. Many people seek opportunities through the ELM for career development and training, involving periods abroad of varying lengths. The group includes many nurses, and also young people in the very early stages of their careers seeking experience in overseas environments. It also includes those in later career stages whose moves may be seen in the context of "chasing the dollar".

g) Clergy and missionaries. Religious and quasi-religious orders traditionally post their adherents abroad, for varying lengths of time. Those staff involved may overlap with other types of expatriates, especially health care and educational professionals.

h) Entertainers, sportspeople and artists. This is a very varied group, frequently moving internationally, often for short periods. Others may, in effect, become permanent migrants.

i) Business people and the independently wealthy. This group may be entrepreneurial, perhaps over several generations, or be investors settling abroad for personal (including tax) reasons.

j) Academics, including researchers and students, in institutions of higher education. There is a substantial exchange of academics and researchers from universities and similar institutions, for varying periods of time. Some moves are relatively short-term, perhaps for an academic session, others are more permanent (the classic brain drain phenomenon). An increasing number of young people take up study abroad, both at first and higher degree level.

k) Military personnel. These are normally excluded from consideration as migrants, and most members of the armed forces would probably not be regarded as highly skilled. However, substantial numbers of officers and specialists would undoubtedly come into a definition of 
the highly skilled that included the military. Periods spent abroad in the armed forces may influence subsequent civilian migrations.

1) Spouses and children of the above might reasonably included in any assessment of the total migration associated with the highly skilled, although in strict labour market terms their inclusion could be questioned.

The motives behind the migrations of each of these types vary. For a majority of them moves reflect the priorities employers use in allocating their staff resources internationally. In other cases moves reflect the incidence of overseas projects and the need to employ contract staff for limited periods. For some people, motivation reflects their individual decisions and aspirations, for example entertainers and those moving for private career development and training purposes. Some highly skilled may also be selected by government entry and permit policies for particular treatment, for example entrepreneurs and the independently wealthy.

\section{Current data problems}

Despite the obvious importance of migration by the highly skilled to the development and management of the international economy, knowledge of the patterns and processes of their movement is poor. There are few accessible data on the scale and nature of their migrations. Partly this is because their small numbers easily render them statistically "invisible", particularly in sample surveys like the European Labour Force Surveys (LFS). It is also because such people are not perceived to be a "problem". In Europe, many of them are EU or Nordic nationals migrating within free movement systems, so they may escape statistical accounting. A recent study (Salt and Singleton, 1993) demonstrated the difficulties of obtaining much by way of an occupational breakdown on stocks of foreign workers in Europe, let alone the much smaller flows. It may be possible to compile statistics on the highly skilled at an aggregate level from the LFS, but this would require a major statistical research exercise.

A major difficulty is that statistical systems inevitably have difficulty coping with an occupational group so ill-defined. There is no commonly agreed international definition of the highly skilled, and the breakdowns used by different countries are not necessarily comparable, even where data are available (as in the New World immigration countries). A particular problem is that highly skilled migrants often move on a temporary basis, for well-defined periods, and are omitted from those analyses that include only permanent (landed) immigrants. This remains a major problem in comparing labour migration in the Old and New Worlds.

These difficulties must be borne in mind when interpreting the tables in this report purporting to list stocks and flows of highly skilled migrants. The data have mainly been culled from the database of the Migration Research Unit at University College London. This is a comprehensive statistical database for European countries, compiled during a series of research projects in recent years. It includes data from national statistical offices, from the Eurostat database (including the LFS), and from the OECD.

The lack of comparable data (any data in many cases) on the highly skilled is immediately apparent. Most countries are able to produce some "occupational" data on foreign workers, but the statistics more often than not record industrial sector rather than occupation. Hence, all skill levels are grouped together, so that the numbers of highly skilled in an industry cannot be differentiated. In some cases level of qualifications is used to indicate who is highly skilled, in others categorisation is by the occupation recorded. Countries use different occupational breakdowns, and in some cases they are more detailed than in others. Often broad terms, like "scientists" or "administrators", are listed, with the attendant 
uncertainties about who and what is included. Language is a further barrier to comparability, since exact translations of technical terms may be difficult.

Countries use a variety of sources to produce data. Work permit data are usually the most complete with respect to occupation and qualification, but in free movement zones omit a large proportion of the foreign population. Most countries with residence permits or population registration do not collect statistics on detailed occupation or qualifications. The LFS is potentially a rich source for Europe because of the large number of questions it asks (including level of education). However, it is a sample survey, and rapidly becomes fallible when broken down by nationality and other characteristics. New World data are generally good, especially on permanent settlers, although the interaction in their labour markets of landed and temporary immigrants is not always clear. Elsewhere, for example in parts of the Asia-Pacific Region (APR), data are derived from a range of official and other (including employers' representatives) sources. In these circumstances comparability is almost impossible and the best that can be hoped for is an indication of overall levels of magnitude and trends in flows.

\section{Highly skilled labour in the modern economy}

\section{The development of a skills market}

Flows of highly skilled labour occur within a new global division of labour which has resulted from the restructuring of the world economy. New technologies have revolutionised both processes and products, altering the equation between capital and labour. The sectoral structure has changed dramatically over the last two decades or so, with major job losses in manufacturing, while growth has occurred principally in the service sector. As the speed and reliability with which people and goods could be moved between regions has increased, so has the geographical distribution and complexity of industrial organisations able to exploit the newly accessible territories.

The principal flows of highly skilled workers today reflect the global expansion of world trade, the international expansion of trans-national corporations (TNCs), and the activities of institutions such as government departments and recruitment agencies (Findlay, 1990; Salt, 1992). This has meant the evolution of a pattern of migration dependent less on the aspirations of individuals to move as in other forms of migration, and more on changing patterns of demand and the development of an organisational infrastructure under which the moves take place. This infrastructure includes a system of hierarchical career development, together with a rewards package which is designed to minimise the financial and psychological impact of migration on the individual and his/her family.

Many governments agree on the advantages to their economies of more or less open borders for high levels of skill and expertise, although more recent indications suggest that attitudes are becoming more sceptical. Recognition of the importance of migration by the highly skilled partly underlies policy decisions by the some countries. For example, Australia, Canada and the US have developed programmes to increase the numbers and proportion of the highly skilled in their overall intake. These developments draw attention to the international immigration market among the highly skilled (Borjas, 1990). This market is a feature of the development of a global economy characterised by the internationalisation of companies and of human resources. 


\section{The role of highly skilled labour in economic development}

Attracting foreign investment and associated skills has become a major element in the economic development process for many countries. However, while there is considerable information on the scale of investment flows, data are limited on the scale and nature of accompanying (or reciprocal) movements of skilled staff.

There seems to be a positive general relationship between flows of skilled labour and of investment, as Table 1 suggests for Japanese investment in Asia. In detail, however, this relationship is less clear: Thailand, for example, has received 9.3 per cent of Japanese investment, but has a fifth of Japanese expatriates. These differences probably reflect the interplay of local factors, the nature of the investment, and the time period over which it has taken place (Boyle et al, 1994).

The need for foreign investment, often only available with an accompanying inflow of foreign labour expertise, has encouraged many developing countries (e.g. Indonesia, Malaysia and China) to adopt a more open position with regard to skilled labour immigration. In Singapore, Malaysia, Taiwan and Thailand, foreign firms are allowed relatively easy access to foreign skilled manpower (Fong, 1993). At present, however, they see this inflow as a temporary phenomenon. This more open position may be reinforced if it is accompanied by politically-initiated regionalisation of the international labour market. This has already occurred in the EEA, partly in North America between the US and Canada, with, prospectively, Mexico following.

The Newly-Industrialised Economies (NIEs) are not only receivers of high level skills; increasingly they are involved in complex networks of skill exchange of their own (Ong et al., 1992). As they have spawned their own multi-national operations they too have increased their numbers of expatriates (Findlay et al., 1996). China, for example, receives increasing numbers of temporary PMT workers from elsewhere in the Asian-Pacific Region (APR). For these new TNCs the current process of expatriation seems principally to be an escape from increasing labour costs at home, rather than as part of a similar internationalisation strategy to that practised by the Japanese, Americans and Europeans. But there is every reason to believe that such a strategy for the NICs will continue to evolve, since there is a close symbiotic relationship between the adoption of this strategy by developing countries and the internationalisation of business by large first-world corporations.

The extent to which TNCs transfer their own nationals to the sites of their overseas operations varies, both by nationality and the degree to which companies have become global. Japanese companies have followed a policy of shifting production to third world countries, accompanied by their own managerial expertise rather than recruiting local skills. This strategy also seems to have been adopted to some extent by their regional neighbours -- Hong Kong, Singapore, South Korea and Taiwan -- although they appear more willing to employ third country PMT staff (Fong, 1993). Japanese companies seem less likely than their American and European counterparts to recruit local managerial staff. One consequence of the internationalisation process for TNCs is the spread of particular management practices, American in Europe, Japanese in the APR, for example.

\section{Government management of migration by the highly skilled}

There seems little doubt that for a multiplicity of reasons the volume of international migration in the world is rising. One consequence in the developed world in general has been a growing concern with the management of migration flows (Cornelius et al., 1994). Increasingly countries find themselves in the position of developing policies to exclude certain types of migrants, while at the same time allowing entry to 
those their international commitments oblige them to take (e.g. member nationals from free movement networks like the EU; refugees), or those whose presence is deemed economically desirable. The highly skilled may be found in both groups.

Although there is a consensus that certain people should be allowed to pass more or less freely across borders, there is no guarantee that states will agree on the same categories. Most OECD member states operate some form of selective labour entry which emphasises the virtues of skills and youth. However, these criteria are usually flexible enough to accommodate workers for whom entry restrictions have been removed or minimised. Increasingly the highly skilled have come to move more freely as work permit systems have changed to accommodate the global search for expertise. In the New World such people are identified on labour market grounds in lists of preferred occupations. Outside these groups of skilled workers there is a general trend towards tighter control. Indeed, in most of Europe "primary" labour migration has largely ceased.

A recurring theme underlying the management of the migration system is a process of immigrant labour selection. It operates in the New World via points systems and preferences, government being the principal agent of selection. In Western Europe, the labour market has tended to be the locale for selection, especially for migration by member nationals within the EU. For third country nationals, employers make decisions, subject to a set of government-imposed guidelines operated through work permit systems. One UK study concluded that the work permit system intrudes little upon manpower planning and the flow of highly skilled labour from overseas, because of a massive adaptation to the system by large employers. They put a lot of effort and expense into pre-selection, so that when an application is made the right support is there to make success likely. An overseas manpower planning system has thus evolved in which the work permit system has become a fixed and predictable element. In the NICs the migration of high level skills is associated especially with foreign direct investment (FDI) flows. Here the scale and composition of migration are more likely to be dictated by the policies of investors: Japanese overseas investment, for example, is usually accompanied by relatively high levels of corporate transfer.

As far as governments are concerned, it is by no means clear where the focus of labour selection lies, however. At a simple level, the "state" decides. In effect, decisions are taken at different points in the governmental apparatus, with different ministries responsible for different elements in selection, leading to difficulties in coordination. The immigration of (non-EU) highly skilled staff to the UK, for example, may involve three government departments (Home Office, Foreign and Commonwealth Office, Department for Education and Employment).

Private employers have an important voice, though their freedom to recruit varies considerably, both between and within countries. Where free movement provisions exist, employers face few restrictions on their ability to recruit abroad. They also face few restrictions on their ability to recruit high level skills, especially if they are large TNCs.

\section{Empirical evidence of current stocks and trends of highly skilled migrants}

The paucity of hard data referred to in Section 2 means that any attempt to determine the scale of migration by the highly skilled must be uncertain. However, three general conclusions are possible:

- compared with the totality of international migration (excluding asylum seekers), the volume of migration by the highly skilled and their dependants is small. 
- stocks of highly skilled foreign workers are nevertheless considerable, and seem to be increasing.

- it would appear that flows of highly skilled migrant workers are increasing at a faster rate than those of less skilled legal migrant workers.

\section{The New World}

The relationship between migration intake programmes and the state of the labour market in the New World countries is a complicated one. In each of the three major countries -- Australia, Canada and the US -primary labour migration is a small proportion of total immigration which is dominated by family movements. Each of them, however, has taken steps to increase the skill level of the labour intake during the last decade.

In Australia, for example, the skilled proportion of the intake tripled from 1984/5 to 1989/90. The FitzGerald Report argued forcefully that the immigration programme needed a high proportion of skilled, entrepreneurial and youthful immigrants, with English and other language skills playing a part in selection. There seems to have been little research, though, on the relationship between increased skill immigration and job training in Australia. While Australian governments have embraced the permanent immigration of skilled workers, they have been ambivalent until recently about temporary inflows (Brooks et al., 1994). In 1991/92, 19200 visas were issued to skilled workers permitted entry for a limited period, mainly to overcome shortages. Of these, 2300 were for corporate transferees, 14900 for skilled specialists. The main sources of skilled temporary residents are Australia's principal trading partners, the major sources of foreign capital and destinations for Australian investment abroad. By 1995/96 the number of temporary visas for skilled workers had fallen to 15 400. However, in 1995 the Australian government introduced a new short-stay visa for business people entering Australia for periods of less than three months, and to complement this brought in a new long-stay visa in the following year to cater for business people and key personnel entering Australia for periods of three months to four years.

In the early 1990s a decreasing number of immigrants to Canada were selected for their potential economic contribution, declining from 18 per cent in 1990 to 15 per cent in 1992. In response to this trend, new immigration procedures, ratified in February 1993, have given the Government more control over the management of immigration and introduced a comparative basis for immigrant selection, resulting in a new focus upon immigrant skills. New selection criteria reflect the rapidly changing needs of Canada's labour market, with less emphasis upon specific skills and more emphasis on knowledge. The skilled worker component among landed immigrants rose from 25 per cent in 1993 to 38 per cent in 1995 In contrast, the recent trend in business class immigration has been downward, from 13 to 9 per cent over the same period. By far the top three sources for business class immigrants are respectively Hong Kong, Taiwan and South Korea, which together accounted for 61 per cent of this category in 1995.

The same growing commitment to increasing the skill levels of the labour component in immigration programmes is seen also in the US 1990 Immigration Act. Highly skilled workers and their families are a major element in employment-based permanent immigration. The 464600 non-immigrant worker admissions in 1995 were also dominated by the highly skilled, including professionals, intracompany transferees and treaty traders, investors and dependants. 


\section{Western Europe}

The Netherlands is one of the few countries where some indication may be had of the importance of the highly skilled. The trend has fluctuated. The three categories of scientists etc., managers and executives, and administrators increased their number of foreign workers from 57000 in 1987 to 62000 in 1995, a 19 per cent rise, but this was less than the 26 per cent increase for all foreign workers (Table 2). In 1995 these three occupational groups accounted for 28 per cent of all foreign workers. Nearly three-quarters of them came from other EU countries, a slightly higher proportion than just a few years earlier, indicating that the Netherlands has been receiving relatively fewer people in these groups from elsewhere. The importance of the highly skilled in the Dutch labour immigration stream has fluctuated, however. Between 1987 and 1992 their numbers rose at a higher rate than that for other labour immigrants, and a higher proportion came from outside the EU (Muus, 1996). It would thus appear that in the mid-1990s both numbers and the proportion of the highly skilled have fallen compared with the late 1980s and early 1990s, at a time when the Dutch labour market was generally weak.

For France, the 1990 Census records a stock of about 200000 foreign workers in PMT categories, 12.5 per cent of all foreign workers (Table 3). About 85000 (42 per cent) of these were nationals of other EU countries. Analysis of trends in the characteristics of new permanent workers shows a fluctuating fall in numbers of PMT staff, but an increase in the proportion of the total to over a third in 1995 (Table 4).

Evidence from Germany, too, supports a trend towards more mobility among the highly skilled (Werner, 1991). Whereas the overall employment there of foreign nationals has been going down, that of foreign graduates has increased.

Indirect evidence for Belgium shows that, compared with the indigenous population, foreigners are less likely to be in white-collar occupations (Table 5). However, there are variations by nationality: those from the US and UK are overrepresented among executives, while those from non-EU Mediterranean countries especially are predominant in blue-collar occupations (Vranken, 1992).

For Luxembourg there is indirect evidence of increasing use of high level foreign skills. In 1990 a third of all new foreign workers (5 400 out of 16900 ) were in the insurance, banking and finance sector (characterised by high levels of skill), up from about a quarter in 1980.

In the United Kingdom the existence of unpublished data on the scale and characteristics of highly skilled migrants, together with a body of recent research, allows some conclusions about the scale, trends and composition of this form of migration. Throughout the period 1980-94 around 60 per cent of immigrants and emigrants in employment (as recorded in the International Passenger Survey) were professional or managerial workers (Table 6). The total volume of PMT flow is considerable, with a gross annual movement of around 137000 in 1994.

Work permit data reinforce the importance of the highly skilled inflow. Work permits apply only to nonEC citizens, so numbers are lower than those recorded by the IPS. In 1995, 13300 long-term work permits were granted to people in professional and managerial occupations (Table 7), about 78 per cent of all long-term issues. Numbers have risen steadily since 1991. Consistently about four in five work permits go to highly skilled foreigners.

A third view of the role of highly skilled immigrants in the UK labour market may be derived from the Labour Force Survey. Table 8 gives stock figures for foreign nationals in 1995, broken down by socioeconomic category. Overall, there were about a quarter of a million foreign nationals classed as professionals, employers and managers in 1995, the majority (67 per cent) male. Among the total stock of 
workers, foreign nationals are more likely than UK nationals to be professional and managerial workers ( 28.5 per cent compared with 23.3 per cent), non-EU nationals particularly so ( 30.2 per cent). This tendency is more so for males than females: 36.1 per cent of foreign men, but only 17.5 per cent of foreign women, were in the highly skilled category. This difference between the sexes reflects the fact that the international executive career is much more a male than a female phenomenon.

\section{Nordic Countries}

Nordic countries also demonstrate the significance attached to skill in primary labour immigration, although the full picture is hidden by the lack of data on Nordic nationals, who have free access to labour markets there.

The socio-economic status of foreigners of all age groups at work in Finland is higher than the average for Finns. About 30 per cent of foreigners in 1990 were upper white collar employees, compared with 13 per cent of Finns. They were also over-represented in the education and research sector. Non-Nordic immigrants are mainly from Germany, the UK or the former Soviet Union. Nationals of the first two are mainly PMT workers who do not come to settle, in contrast to the less skilled people from the FSU. Work permit policy is to issue mainly in fields requiring professional skills. Occupational selectivity occurs: language teachers are often British or French; musicians come especially from Eastern Europe; Germans and Swiss are often found in managerial posts in business and commerce. In contrast, southern Europeans, Africans and Asians are more often in low-paid service occupations.

In Sweden, only 190 work permits were issued in 1995 (300 in 1991), almost all to specialists, artists, and key employees of multinational companies -- persons who seldom intend to settle in Sweden for any length of time. In recent years numbers of work permits given to Europeans have been declining, with more going to Asians, especially Chinese, and Americans. Temporary permits, numbering about 14000 in 1995, are mainly used to deal with temporary shortages of qualified labour (Ornbrandt, 1996).

The deficiency of data on occupational characteristics also affects Norway, for there are no statistics on the employment of the foreign population as a whole since the 1980 census. However, a special survey in 1990 showed that the foreign population in Norway had a higher level of education than the indigenous population: 22 per cent of the foreign-born had a degree, compared with 15 per cent of Norwegians. Further, Norway has been trying to attract more foreign students, as part of a general attempt to internationalise Norwegian higher education and research. During the period 1990-93, around 60 per cent of the 1200 or so per year non-Nordic labour migrants entering the population register were specialists (Table 9).

\section{Southern Europe}

Data are particularly scarce on highly skilled migration in the Mediterranean region. In Italy, the majority of foreign workers are not qualified, but the number of specialist workers has been increasing (Montanari, 1995).

In Portugal, over a third of foreign workers with residence permits, about 20000 in all, were professional or scientific, higher managerial, or administrative workers in 1991 (Table 10). During the period 1989-91 the rate of increase of each of these groups (especially professional, scientific and higher managerial) has been significantly higher than that of other types of labour. The proportions of total residence permits accounted for by these highly skilled groups vary with origin: 60 per cent of Europeans fall into these 
categories, 57 per cent from North and South America, but only 11 per cent of those from Africa (OECD, 1993).

Spain, too, shows evidence of increasing employment of foreign skills in the late 1980s and early 1990s., but with a sharp subsequent fall. Work permit issues to PMT workers rose from 12900 in 1987 to peak at 23100 in 1991, before falling to 7700 , only 8.4 per cent of the total, in 1994 (Table 11). The inflow of professional and technical workers was particularly strong, doubling over the five year period 1987-91, compared with only a 13 per cent increase in total issues. The majority of highly skilled immigrant workers were from the EU, especially from those countries with strong economic relations with Spain in commerce, manufacturing and finance: the UK, Germany, France and Italy. About 50 per cent of British people issued with work permits were PMT, around a third of those from Germany, France and Italy. However, the figures for the US and Japan were higher, 74 and 55 per cent respectively (Rodriguez, 1995).

\section{Eastern Europe}

The brain drain from Eastern Europe is discussed in Section 8. However, there is growing evidence that here too the immigration of high level skills is increasing.

In the Czech Republic most work permits to western Europeans are for highly skilled workers, mainly in professional and managerial occupations, consultants and language teachers. In 199321 per cent of valid work permits (2 100 out of 10300 ) were issued to the nationals of Austria, Canada, Germany, Italy, the $\mathrm{UK}$ and the US.

Poland experienced a rapid increase in work permit issues, to 12000 in 1992, but falling to 10400 in 1995. Analysis by occupation for issues in 1996 shows the dominance of skilled workers, nearly twothirds of whom were in the highly skilled category, and another ten per cent were classed as skilled.

In Hungary around a third of work permits in 1995 went to non-manual workers, of whom 55 per cent were highly qualified. In Bulgaria, about three-quarters of the 618 work permits issued to foreigners in the period 1994-96 were received by senior managers, consultants and teachers.

\section{Asia-Pacific region}

The migration of highly skilled Asians is one of the most important components of the global migration of PMT workers. In the 1950s and 1960s it mainly took the form of brain drain out of the region; today migration of skills within the APR is more characteristic, combined with the return of earlier skilled emigrants. The US, with Australia and Canada to a lesser extent, has been the destination for much Asian emigration. For example, about 200000 Asians with training in the science-based professions entered the US from India, South Korea, Philippines and China between 1975 and 1988 (Ong et al., 1992).

In 1990, some 14600 Singaporeans (5 per cent of the country's managers) were working overseas, only half of them in Asia (Straits Times, 1992, quoted in Fong, 1993). Most work for Singapore-owned companies. In addition, thousands of Singaporeans cross weekly into Malaysia on business-related services. An estimated 30000 foreign PMT workers are employed in Singapore; in all, skilled foreigners account for about 2 per cent of Singapore's total workforce, and 10 per cent of the highly skilled. About a third of this skilled workforce comes from other countries in the APR. This dependence is part of a longterm strategy to attract the highly skilled, including granting permanent residence to them. 
Indonesia is estimated to have 50000 foreign professionals working in the country, mostly for foreign TNCs; Malaysia had an estimated 20000 in 1992. However, numbers in Taiwan seem relatively low, though growing (Kanjanapan, 1995).

In 1980, 37000 Japanese were transferred to overseas branches by their companies, plus another 6000 sent abroad temporarily to provide services; in 1989, the equivalent numbers were 97000 and 15000 (Japanese Annual Statistical Abstract, 1991, quoted in Fong, 1993). Japan's Ministry of Foreign Affairs estimates that 34000 Japanese expatriates work for private companies in Asia, plus around 42000 in North America and 26000 in Europe.

One estimate puts numbers of skilled and professional Taiwanese working abroad at 120000 (Lee, 1992). It is suggested that Taiwan's firms are more profligate in their employment of skilled expatriates than those of other countries, a consequence of an entrepreneurial style that prefers to employ its own people in what are frequently still family-owned firms (Chan and Weng, 1991, quoted by Fong, 1993).

An estimated 50000 Hong Kong residents cross the border each day to manage factories in South China (Far Eastern Economic Review, 1991, quoted in Fong, 1993).

\section{Latin America}

Trends in migration among highly skilled Latin Americans have recently been summarised by Lamarra (1992). During the 1960s, and increasingly in the 1970s, emigration was the principal characteristic. The US was the main destination, and the 1980 Census recorded about 135000 Latin Americans working as professionals, and a further 105000 as managers.

Since the 1970s, a new migratory flow of professionals has been gaining strength, towards other countries in the Latin American region. This flow now accounts for a third of all moves by qualified emigrants from Latin America. In 1980 the three main receiving countries (excluding Mexico, for which data were not available) were Venezuela, Argentina and Brazil, with respectively 25 700, 18200 and 12200 foreign PMT workers. In Venezuela, the majority of immigrant PMT workers were teachers, architects or engineers; in Argentina they were teachers, nurses or midwives; in Brazil they were mostly architects or engineers, but also included doctors, dentists, lawyers, artists, mathematicians and statisticians.

Flow data are particularly hard to find, but one study estimated for 1965-83 that 35-40 per cent of the average annual flow of Argentinians to the US were professionals or managers, although only about a quarter of them were working in those capacities.

\section{The importance of corporate transfers}

There is little doubt that the skill requirements of TNCs to a very considerable extent underpin the international movement of expertise. This expertise is normally obtained either through the process of corporate transfer, or through external recruitment. This section examines the first of these, using the examples of the UK and the US.

\section{The United Kingdom}

Among the highly skilled, those moving internationally within the ILMs of large employers are a major group. About 11100 of those granted work permits in 1995 (47 per cent of the total) were company 
transferees. The absolute trend in this group has been upward in recent years, though proportionately they have declined, from around 60 per cent a few years ago. When EU nationals are included, as is the case with LFS data, the importance of corporate transferees rises.

During the period 1985-95 about 261000 were working in the UK and living and working for the same employer outside the UK a year previously (Table 12). Of these, some 131000 were foreign nationals, including 98500 from non-EU sources. Overall, the LFS data indicate that about 40 per cent of all foreign national workers, working outside the country the year before the survey, were corporate transferees. Around a third of those originating in the EU (excluding Ireland) and almost 45 per cent of those from non-EU countries were in this category. Data for 1995 indicate about 23000 corporate transferees. During the period 1985-95 the annual average of inward transfers has been about 24000 , of whom some 11800 were foreign nationals and $12000 \mathrm{UK}$ nationals. EU states averaged about 3000 inward transfers per year.

We can use these figures to make some estimate of the total amount of international corporate relocation involving the UK labour market. Let us assume that the 12000 Britons are returning from secondment abroad, and that the 11800 foreign nationals are coming to work in the UK for UK and non-UK owned organizations. Further, let us assume that the average secondment period is two years (empirical research with large organizations has shown this to be a reasonable assumption). Assuming that in any one year 12000 Britons go out, and the same number return it would seem that annually around 24000 Britons are in an expatriate situation within corporate international labour markets. About 11800 foreign nationals come in each year, and a similar number leave after their two year secondment. On this basis, the annual total number of corporate transferees involving companies in the UK would be 47600 .

Perhaps the best indicator of the value placed on international PMT workers is the amount employers are prepared to invest in their relocation. One recent study (Salt, Mervin and Shortland, 1993) estimated that the average net overseas cost per executive was about $£ 87500$ per year. On this estimate, TNCs in the UK are spending about $£ 4.2$ billion (US\$ 6.3 billion) per year on moving their highly skilled staff. The enormous cost of relocation, however, suggests that employers are under continuing pressure to consider other, less expensive, ways of moving skills internationally. This point will be taken up later.

\section{The United States}

In 1994, about 98000 foreign intra-company transferees were admitted to the US; this figure being more than double that for 1981 (Table 13). They were accompanied by around 56000 dependants. Europe was the principal source region, accounting for 46 per cent of the total. The significance of America's corporate partners is also clear: the UK and Japan between them were responsible for 36 per cent of the total (Table 14). There are no similar data on the number of US nationals abroad on secondment.

However, some information on the scale of corporate transfer activity for US companies is available from the latest survey of a sample of 180 of its members carried out by the US Employee Relocation Council (Employee Relocation Council, 1993). In 1992 respondent companies transferred an average of 18 employees out of the US and repatriated 15. Non-US companies had lower rates of transfer, averaging 11 in and the same out per annum. The average length of assignment was 18 months, with 40 per cent being 2-3 years. The average number of employees out on assignment was 68 per company, only four of whom were female. The median was lower, 20 per company, although individual companies ranged from zero to 990 . Numbers for non-US employees were smaller, averaging 27 per company (range zero-400), with a median of eight. 
Making similar cost assumptions to those for the UK above, the annual expatriation cost per US company in this survey would be about $£ 6$ million (US\$9 million).

The significance of these financial calculations is twofold. First, they give us some idea of the levels of benefit companies feel they derive from the international transfer of expertise. In interview surveys, most companies questioned have little idea of the quantitative benefits accruing from the recruitment of skills and expertise; any advantage they gain is lost in general profitability. They do, however, have some idea of the costs of transferring skills, as illustrated above. It is a reasonable assumption that these costs are thought to be justified by making available the expertise where it is needed. In these terms, therefore, the costs of relocation provide a rough indication of the value of the international relocation of high level skills. That value is clearly very high. Second, the sums involved in corporate relocation are extremely high when compared with the resources made available for other forms of migration. Almost certainly they dwarf, for example, the international asylum budget.

The migration of high level skills may not be vast numerically, but it is financially. The corporate rationale for this is explored in the next section, where particular attention is paid to the relationship between external and internal labour market recruitment.

\section{Modern business organisation and the highly skilled}

The pattern of employment of internationally mobile highly skilled workers is closely associated with the evolution of business structures. For example, electronic engineering companies, almost by definition, are highly organic, changing their character to take advantage of new products and technologies. They need ILM structures that provide them with maximum flexibility to respond to new staffing requirements. For many, the high cost of new developments in high-tech industries has encouraged them to enter into business consortia with international partners.

\section{The use of overseas labour}

Empirical studies of international migration by the highly skilled are rare. One UK study, carried out in 1989-90, looked at four sectors: finance, electronic engineering, health, and hotels and catering. Its principal conclusions are instructive in demonstrating how little effort is put by employers in recruiting internationally through the ELM.

In the study, firms were asked about the extent of their labour shortages, and the role of overseas recruitment. In all sectors three things stood out. First, that extensive use was made internationally of corporate ILMs. Most of this movement was for career development and training reasons, designed to produce staff able to cope with a wide range of professional and managerial situations.

Second, most recruitment of foreigners through the ELM involves labour already resident in the UK. Few firms had made little attempt at recruitment abroad (with the exception of Ireland). The main reasons for this were twofold: (a) many of the shortages they were experiencing were endemic (e.g. software and systems engineers), and low UK salary levels were unlikely to be sufficient to attract them in competition with other developed economies; (b) for the most part, companies were unaware of what pools of foreign expertise existed, and how they might be tapped. In the last analysis, the ELM is not yet well enough organised for specific skills to be efficiently marketed, with the major exception of those at the highest level who are headhunted. 
The reasons for recruitment abroad in the ELM are complex, but there has been little systematic study of the process. A study (Larsen, 1993) of graduate Norwegians working abroad found that only 28 per cent of them had been transferred abroad, the others had used the ELM. The latter, however, were more likely to have sought jobs abroad, rather than responded to recruitment advances. There were also variations by specialism and destination. Research into graduate recruitment in the rest of Europe by UK companies suggested that labour shortages were not an important reason (Pearson, 1992). Companies were particularly concerned to develop their European business links, with development of European international careers for their staff also important, but to a lesser extent. The significance of these data is that they suggest that alternatives to recruitment or transfer of staff may be more viable options in the medium and long term. Companies can develop foreign links in other ways, through take-overs, joint ventures, or the use of overseas sub-contractors, without incurring the expense of recruitment to their fulltime staff.

ELM recruitment is a particular feature of those companies with infrastructure contracts abroad. Frequently they use international recruitment agencies, which themselves normally keep lists of potential recruits, often workers from previous contacts. One of the few studies of the activities of these agencies found that over 60 per cent of a sample of workers they handled were in professional or managerial employment (Findlay and Garrick, 1990). The majority of this sample gave high wages as a motivation for moving abroad.

These results, and those of other studies, imply that not all of the movement and recruitment of foreign skills is initiated by the demand side (King and Shuttleworth, 1995; Chen, 1996; Li et al., 1996). Many overseas nationals come to the UK as part of their own training and experience plan, Irish nurses and young foreigners in the hotel and catering sector being good examples. This is one reason why many, perhaps most, foreign highly skilled workers are already in the host country at the time of their application for recruitment.

\section{Does overseas labour increase the employer's flexibility?}

The flexibility brought by management career development policies, and by project secondment, is of a different order to that resulting from ELM recruitment of overseas nationals to fill particular vacancies. This was seen in the UK study in comparisons between most of the movement occurring in the finance and engineering sectors on the one hand, and in the health and hotel and catering sectors on the other.

For many large employers, the ultimate flexibility comes from being able to apply relocated executive to desk, or specialist technician to project, with the greatest possible speed. Being able to use the full human resources of the company, wherever located, is what matters. Flexibility is also derived from having an adaptable workforce, with wide experience in different locations, and the ability to transfer skills between locations. Career development programmes are designed to achieve this end, especially when they provide training in several functions: the corporate polymath is often to be found in the higher echelons of decision making.

Evidence that flexibility is increased by the use of overseas workers who are not corporate transferees is limited. Before recruiting overseas firms prefer to explore the potential flexibility of their existing workforces and of new indigenous sources. 


\section{Skilled international migration: the East-West "brain drain" in Europe}

During the 1990s there has been an increasing literature on emigration from Eastern and Central Europe by the highly skilled. At the Latina conference in Italy (October 1993), for example, no fewer than six papers dealt with the subject. The aim of this section of the report is to summarise the main trends in East-West migration by the highly skilled, and thus indicate its future course.

The growing interest in the phenomenon has taken place within a vacuum of systematic data. There are at present very few statistics on the quantity or quality of the current brain movement from East to West (although a UNESCO-ROSTE taskforce considering "Brain Drain Issues in Europe" is presently seeking to rectify this). In summary, what exists are a number of data sets and studies:

- showing the decline in employment in the scientific sector for several countries of Eastern Europe and the former Soviet Union (FSU);

- concerning the arrival of scientific personnel from Eastern Europe and the FSU in countries of Western Europe;

- conducted amongst scientific personnel still in the East concerning their future intentions regarding international migration.

These data do not indicate the massive actual and potential brain drain from East to West, with negative impacts upon sending countries, that is sometimes suggested. In fact the East-West brain migration needs to be disaggregated. First, there seem to be different processes occurring in the FSU compared to other countries of Eastern and Central Europe. Second, the impact of the migration upon sending and receiving countries and the migrants themselves is mediated by a distinction between nationalist $v s$. internationalist vs. behavioural perspectives; internal vs. international brain migration; and brain drain vs. brain gain vs. brain waste.

\section{Current patterns and processes of East-West brain migration}

After the collapse of Communist regimes in the Eastern bloc, their science sectors were relatively overstaffed yet underfinanced. The subsequent reduction of staff in these sectors occurred very quickly. From 1990-91 Bulgaria cut its scientific staff from 86300 to 65300 , i.e. 25 per cent, and further in 1992 to 47 000, i.e. a further 28 per cent (Rhode, 1993a). Similarly, employment of public sector scientists in Russia fell by about 300000 in the past 5 years to 1991 to about 3 million, and between June 1991 and June 1992 scientific employment fell by a further 13.7 per cent (Rhode, 1993b). Although the problem of overstaffing was less in central European countries, the decline has still been significant. Employment in the science sector in the former CSFR declined from 108400 in 1989 to 65600 in 1991.

Even though the science sectors were relatively underfinanced, they still received a large annual investment in relation to national GDPs: 4.5 per cent for the former Soviet Union in the mid-1980s and 4 per cent for the former CSFR in 1989. The financial crisis which came with collapse means that in most countries this has been reduced to under 1 per cent.

What has been suggested is that the drastic reductions in employment and investment in the scientific sector following the collapse engendered an East-West brain migration which was quantitatively and qualitatively different from previous East-West brain migrations. Although overall data do not exist, there are specific indicators for certain countries. They indicate that there are very different processes occurring 
in the FSU compared with the other countries of the Eastern bloc. Only in the former does it seem that the collapse and subsequent decline in employment and investment in the scientific sector has resulted in increased brain migration.

In Poland between 1980 and 1991, 9.5 per cent of scientific personnel left the country (Hryniewicz et al., 1992). However the rate of loss decelerated after the collapse in 1989: the average annual loss of 0.86 per cent between 1981-91 decreased to 0.67 per cent between 1989-91. This deceleration was also confirmed by Korcelli (1992). In 1991 the Hungarian Academy of Sciences estimated that 15 per cent of all Hungarian researchers were working abroad, and the majority of these intended to stay abroad for several years. One year later it appeared that the number of Hungarian émigré scientists had also decreased. In contrast 1991 was the year of highest emigration from the FSU, when some 90000 scientists and academics left.

There are two possible explanations for these trends. Hryniewicz et al. (1992) suggested that migration trends over the past 10 years in Poland had corresponded with political events. Of the 2700 who migrated from their surveyed institutions in total over the period, 44.6 per cent left in the period 1981-84, the years of martial law; 34.1 per cent left between 1985 and 1988, during which time there was a considerable relaxation of repression, and 21.2 per cent left between 1989-91, after systemic changes had started. It would thus appear that political relaxation has been a "holding" factor which in fact decreases rates of brain migration. This may be true for all the countries of the Eastern bloc.

How then to explain the anomaly of increasing brain migration from the FSU? Rhode (1993a) has shown that 45 per cent of the 90000 scientists or academics who left in 1991 were Jews who arrived in Israel. A further 37 per cent were ethnic Germans who went to Germany. It would seem that these were ethnic migrations as opposed to brain migrations, of groups who made up a high proportion of the scientific and academic community in the FSU.

What both these analyses point to is the need for an analytical distinction between brains who migrate because of the collapse of their sectors, and people who migrate for other reasons who are also brains. For the former, the main reasons for migration can be identified as: the economic situation of domestic scientific sectors; the financial situation of scientists; the environment and equipment of the workplace and the accessibility of knowledge and information (Hryniewicz et al., 1992). For the latter, the main reasons for migration can be identified as ethnic; political (Rhode, 1993a), and better socio-economic and living conditions (Kouzminov, 1993).

\section{Impacts of the current brain migration}

The data also suggest that there has been a disparity between the reduction of employment in the scientific sector in countries of the Eastern bloc, and the migration of scientific personnel. This is explained by the fact that the majority of personnel who left the science sector remained within their country but sought employment in alternative sectors, usually the private sector. Hyyniewicz et al. (1992) showed that after 1989 international brain migration decreased while what they term internal brain migration increased significantly. Kouzminov (1993) estimated that what he terms intersectoral movement accounted for as much as 90 per cent of the absorption of the unemployed from the science sector.

The nationalist perspective upon the impact of brain migration emphasises the loss to a country of human capital in which it has invested to another country which has made no investment but reaps the benefits. This is clearly not the case where internal brain migration has occurred. Nevertheless, there is no doubt that higher education and research institutions in several countries of the East have suffered from these 
losses, and that if educational programmes are the key to future economic development, then even the internal brain migration does have a negative long term impact.

At the same time, that is not to underestimate the negative effects which even a small international brain migration can have upon a source country. For small countries especially, even the departure of a few top-level specialists in certain sectors of basic research could lead to the collapse of national scientific schools (Kouzminov, 1993). The migration of just a few highly-skilled specialists could jeopardise the capacity of military conversion in the FSU (Rhode, 1993a). It is not clear whether this has occurred, however Hryniewicz et al., (1992) insisted that those highly-skilled Poles who had migrated from their surveyed institutions had not been disproportionately specialised or outstanding.

Clearly the integration of highly-skilled specialists can enhance various sectors within receiving countries. A study from the UK's Science and Engineering Policy Studies Unit (SEPSU, 1987, 1993) shows that the incorporation of scientists and engineers from Eastern Europe and the FSU had increased in a variety of institutions in the UK over the previous ten years.

However, although data are scarce, a general trend seems to be that scientific personnel arriving from Eastern Europe and the FSU are usually not being incorporated into such valuable sectors in the receiving countries. There are two main reasons.

The first reason is the phenomenon of brain waste. Hryniewicz et al., (1992) found that only 22 per cent of the 2700 migrants (614 persons) who had migrated from their surveyed institutions were still employed in science. Fassman et al., (1993) have observed this process in Vienna's labour market amongst highly-skilled migrants from the the former CSFR, Poland and Hungary (occurring especially amongst women). Furthermore, their findings suggest that some 50 per cent of highly-skilled migrants to Vienna anticipate their dequalification before arrival.

The second reason is the quality of the personnel coming from Eastern Europe and the FSU. Rhode (1993b) suggested that the Soviet science system particularly was characterised by low levels of economic efficiency, nepotism, political appointments and huge and heavy bureaucracies. Furthermore she argued that the inflexibility of the science system, and especially its failure to adapt to new information technologies, can be considered to have contributed to the collapse of the Soviet system.

\section{Forecasting future trends in East-West brain migration}

There have been a number of recent studies of the migration intentions of students and highly-skilled personnel which suggest that brain migration can be expected to continue and indeed increase in pace over the next few years.

Dolgikh (1995) interviewed 10-15 per cent of the research staff at a number of Russian institutions, and concluded that 13 per cent of respondents would be ready to go to work abroad as soon as the opportunity arises. Ledeniova (1995) surveyed 1600 students at several institutions about their attitudes towards emigration, and found that of 70 per cent who had considered going abroad following the completion of their present higher education, 17 per cent had taken active steps towards this goal (e.g. contacted firms or institutions). She concluded that 7 per cent of respondents were positively disposed to emigrate permanently. Even more strikingly, Tikhonov (1995) surveyed employees of Russia's military-industrial complex, and suggested that not less than half of highly skilled workers in this sector were interested in working abroad. All three authors found significant variations in intention rates according to a whole series of demographic and socio-economic factors, which basically suggested that those most inclined to 
leave were the youngest, most able people with the greatest potential in the most important sectors or disciplines for the future economic development of their countries.

However these rather alarming forecasts are tempered by other findings. Hryniewicz et al., (1992), for example, showed that public investment in R \& D in the scientific sector in Poland reached its highest level for over ten years in 1992: between 1981-90 the percentage of public investment in the R \& D sphere decreased from 1.2 per cent to 0.2 per cent, whereas by 1992 it had increased to 2 per cent. They also suggested that for most academic staff, real wages have increased. These two elements of investment and wages were identified by Dolgikh's (1995) Russian respondents to be of central importance in their desire to move. The indication therefore is that, if Poland's recent experience occurs elsewhere, the motivation to move may be reduced.

Dolgikh's (1995) respondents also listed upgraded living standards, socio-economic stability, political stability, foreign research contacts and foreign contract jobs as factors which might persuade them not to move from Russia. Kouzminov (1993) also suggested that familiar surroundings, patriotism, and attachment to a life of routine, might be additional holding factors. There are also a number of obstacles to movement, including separation from friends and relatives; expense of international travel; difficulties of obtaining an exit visa; lack of financial support; inefficient re-entry laws; no place to live abroad; no contract /invitation; and difficulties of obtaining an entry visa.

What is therefore suggested is that despite high and alarming emigration intention rates found during several surveys, there is an indication that conditions may improve, reducing migration motivations; in any case there are a number of holding factors and obstacles which work against potential brain migration.

The most important potential destination countries have been found in all the above surveys to be USA, Germany, UK, and France in that order. The question which arises is to what extent these countries require migrants with the sorts of skills outlined. Western Europe seems to be particularly ambivalent on this question, whereas the USA in contrast already has defined quotas (Rhode, 1993b). Much depends on the willingness of the West to invest in appropriate training which must, by its nature, be an expensive process.

\section{The migration of students}

Literature on migration in the academic sector has traditionally focused on its relevance to the brain drain, and to reverse transfers of technology. However, there are good grounds for arguing that migration associated with the acquisition of tertiary education, and of the skills associated with teaching and research, not only constitutes a form of highly skilled migration in its own right (Li et al., 1996). First, the international movement of students represents the internationalisation of knowledge, and is arguably the most effective vehicle for creating a global migratory elite. Second, the provision of tertiary education internationally is now a major business and source of income, both directly (through fees received in destination countries) and indirectly (establishment of links). Third, foreign students (particularly postgraduates) who stay on in the receiving country constitute a relatively cheap source of skills. Finally, that the volume of international student migration is enormous.

The implications of student migration for home countries largely depends upon whether students return, following the completion of their studies. If they do not do so, then they can be considered to have entered the "brain drain", the implications of which are well-documented (Fakiolas, 1995). 
As student migration, unlike most other forms of migration, can be strictly controlled by host governments, it is not surprising that foreign students benefit host countries. Even where students return to their home countries following the completion of their studies, they can be considered a primarily economic benefit to the host country. For example, the underlying rationale of the Australian Government's policy to attract foreign students has been to increase exports and earn more foreign exchange. There is also a prestige associated with being an international training centre. Equally there is clearly a longer term benefit to be had from the non-return of qualified students. In many highly specialised educational fields in the developed countries, the number of national postgraduate students has decreased during the past two decades to a level below the domestic demand for high-level personnel. The desire to meet this shortfall has resulted in attractive foreign student policy in many countries.

Surprisingly few analyses exist of the processes and trends of migration by students and other academics, and this section attempts little more than to determine some basic trends.

\section{Numbers and distribution}

Although recent data are incomplete, Tables 15-16 provide some indication of the significance of student migration. In 1993, 759400 foreign students were registered as being enrolled at the tertiary level in just 10 selected OECD countries. Other UNESCO data also show significant enrolment of foreign students in the Middle East, former USSR, India and China. Worldwide the number of foreign students in 1993 was in the region of 1.5 million. Trends during the 1980 s varied by destination, though were generally upward.

The USA is foremost as a receiver of foreign students (449 700 in 1993), with France (139600 in 1993), Germany (116500 in 1991) and the UK (95600 in 1992) also significant (Table 15). In total, the European Community in 1991 hosted 479700 foreign students, North America 456 900. The Australian and Japanese governments have both launched programmes to increase numbers of foreign students.

Asia has been by far the largest sending region, accounting for 47 per cent of the total number in selected OECD countries upto 1993 (Table 16). Global data for foreign students show that within Asia China (126 900, 19 per cent of the Asian total) and Japan (59 500, 9 per cent) were the main sources, with significant numbers coming from Hong Kong, Korea and Malaysia. Europe is a major sender as well as a receiver, accounting globally for 345000 foreign students in 1993 (26 per cent of the total), with Germany (41 900, 12 per cent of the European total), Greece (40 700, 11 per cent) and France (27 900, 9 per cent) the largest senders. Africa provided 169000 foreign students (12 per cent of the total), with Morocco (32 100, 19 per cent of the African total), and Algeria (22 000, 13 per cent) the main sources.

\section{Patterns and processes of migration}

The majority of international student flows are from less to more-developed countries: Asia (excluding Japan and Korea), Africa and South America accounted for 564600 foreign students in 1991, or 56 per cent of the total. There are differences in the nationalities of students between countries: 66 per cent of foreign students in the USA are from Asia, 55 per cent of those in France from Africa, and over 40 per cent of those in Germany and the UK from Asia.

Flows of foreign students tend to follow the same channels as other migrants from their country of origin, and can therefore be considered an integral part of migration systems (Kritz and Caces, 1992). The directions of student flows are often dictated by one or a combination of three factors: 
- geographical proximity: for example, over 25 per cent of foreign students in France, Germany and the UK are from other European countries.

- cultural affinity, especially language: English-speaking students tend to favour the USA, Canada and the UK, and French-speaking students France, Belgium and Canada.

- former colonial ties: the majority of African students in the UK, France and Belgium originate from the host countries' ex-colonies.

Nevertheless there are anomalies, and most significantly that of the USA. According to the above factors, one would expect a large number of students from Central and South America in the USA, yet only 4.6 per cent (19 200 of a total of 419600 ) of foreign students in the USA are from those regions. According to Kritz and Caces (1992), language differences, study opportunities elsewhere in their own region, and limited scholarship support account for the under-representation of students from this region in the USA.

The available data do not give any indication of rates of return by tertiary students following completion of study abroad, although new survey evidence is beginning to tackle the issue (Fellat, 1993). However, secondary sources (many increasingly dated) seem to agree that historically return rates are high (Das, 1971; Myers, 1972; Glaser and Habers, 1978; Kritz and Caces, 1992; Fong, 1993). In some cases students may not return immediately following the completion of their studies, some choosing to stay temporarily in the host country for practical experience before returning (Glaser and Habers, 1978). In some cases migration can also become circular, with returned students going again to the country of study largely because economic opportunities at home are no longer commensurate with developed expectations. Such circular migration has been observed amongst Malaysians who had studied in Australia (Kritz and Caces, 1992).

\section{Future trends}

\section{Mobilising the highly skilled}

The thrust of this paper is that the international migration of high level skills is a consequence of the organic process of business development, involving and dependent upon the availability of expertise. Such developments might reasonably be expected to create corporate personnel who are internationally mobile, accustomed and expecting to work anywhere in the world. Their mobility may be in either the external or internal labour market. What they have in common is internationally marketable skills. On the demand side, however, each stage in international corporate development has its own mobility regime. In the first stage, face to face contact with local distributors, involving business trips rather than manager relocation, will probably suffice. Later, there is increasing relocation, of a permanent or semi-permanent nature, as first a domestic sales company and then a manufacturing facility is established. As the company becomes global, the emphasis switches to optimising use of its human resources worldwide. Expertise in any part of the company can at this stage be regarded as mobile in any direction.

What is at issue now is how far this process of mobilising the highly skilled internationally is likely to go. There is some evidence to suggest that for a number of reasons, particularly monetary and human (stress) costs, and also for political expediency, some large corporations have entered a "steady state" with respect to their highly skilled workforce, and are seeking to curb further increases in their mobility by decentralising decision making and by engaging in more localised recruitment and use of their highly 
skilled staffs. The process seems, to some extent, to be cultural: American and European-owned companies have gone farther down this road than Japanese.

This process changes the strategy of overseas staffing involving the highly skilled. Formal systems and organisational structures are important in maintaining a corporate identity in a global environment, but only to the extent that they nurture intangible ties. Decentralisation of responsibility means that managers relocated overseas to "run" a subsidiary country should identify and develop a cadre of local nationals who can take over and run the operation in the long run. Hence, as the organisation becomes multinational it increasingly uses relocated skills and expertise to exercise control from the centre; but after a certain point the trend towards the international relocation of staff is halted and may well go into reverse. We are not yet in a position to know the extent of this process, but it is consistent with the small amount of evidence we have that some "mature" companies now try to minimise international staff relocation and are actively seeking alternatives (Ford, 1992).

\section{Localising the recruitment of skills}

There are two main ways in which this localisation process is occurring: greater use of overseas subsidiaries and collaborators, and of business service firms.

It increasingly seems likely that even large companies from time to time require specialist expertise not available from their own ILMs, even when these are extended internationally. Indeed, the process of internationalisation may itself increase the need for certain skills (e.g. a knowledge of aspects of national legal systems). There is abundant evidence of increasing cooperation among European companies. Collaborative deals involving shared stakes, risks and profits doubled 1985-89, as companies saw the growing need for strategic alliances (KPMG Peat, Marwick, McLintock, 1989). This increase suggests a trend away from costly takeovers, towards the sharing of high expansion costs and of each other's expertise.

Research on the development of business service firms suggests that they may increasingly provide the specialist expertise required by other firms, often working as a complement to in-house corporate expertise (Keeble, Bryson and Wood, 1991). Business service consultancies are especially valuable in the management of unpredictable aspects of organisational development, in particular giving advice on strategic change, organisational restructuring, market trends, information technology and product innovation, and human resource management (Wood, 1994). Transmission of this expertise is through the mobility of expert labour via the branch networks of TNCs, and through the interaction -- frequently international -- of clients and consultants. Survey evidence suggests that the nature of this interaction varies with type of organisation. Those large companies which are more decentralised and multidivisional (characteristics especially of US and European-owned TNCs) make more use of consultancies than those (like the Japanese) which employ more centralised forms of management. The implication for the migration of the highly skilled is that in future the former will tend to make less frequent use of their ILMs in acquiring particular forms of expertise at various corporate locations. In contrast, the latter will continue to do so. The corollary, of course, is that the very particular skills of consultancies will become more mobile, although such mobility is likely to be short-term, more akin to extended business travel than to corporate assignments and secondments overseas.

Some business service employers are themselves multinational, like banks and accountancy firms. Often they follow their clients overseas, supporting clients' overseas subsidiaries as they do parent companies back home. Many business firms are small and localised in their operations within national or even regional boundaries. Much of the work they do for their large, corporate clients is highly specialised and 
cannot be done in house. Although there are as yet few data on the international dimension of this form of client-based provision of expertise, it is likely that it is of growing importance, and may well replace the need for large multinationals either to recruit their own expertise for some functions, or to develop and relocate such staff within their international ILMs.

It would seem from what evidence there is that both large and small business service suppliers serve clients internationally. These suppliers themselves depend upon their ability to recruit and retain high level skills, since their raison d'être is to provide expertise. Where that expertise demands a knowledge specific to particular countries, for example on tax laws or social security regulations, it may be recruited on an international basis, directly or through some form of business co-operation. Increasingly, however, the costs of acquiring this highly specialised expertise are such that more and more employers will subcontract for it on an "as you need" basis. It seems likely that the consequence will be the evolution of a highly skilled elite, with very specialised skills, employed on a sub-contractual basis for limited periods. In so far as business services and consultancies will develop on a local (national) basis, international secondments and assignments will diminish in importance. Expertise will thus be acquired locally, through business travel, or as is likely, through the use of new information technologies and international networking.

These developments also have attractions for the individuals involved. It has been reported that engineers with specialist skills may do better financially as independent consultants because few companies can offer a consistent flow of work. Furthermore, in more organic organisations, rapid technological advances lead to the assembly of teams of highly skilled specialists for a particular project. At its conclusion, the team is dispersed. In these circumstances it makes sense to use a specialised business service firm.

\section{Making more use of air travel}

The speed and dense network of modern air travel has made it much easier to disseminate global expertise. Intuitively, it might be expected that the high costs of staff relocation (especially financial for the TNC, stress and family problems for the employee) or foreign recruitment might be obviated by increased levels of business travel. It would then follow that business travel might substitute for migration. Migration studies have traditionally eschewed consideration of short-term visits within mobility regimes, but there are some grounds for thinking that migration, secondment, short-term assignment and business visits are increasingly substitutable (Salt and Ford, 1993). For example, modern air travel means that it may no longer be necessary to have a permanent expatriate presence with a major overseas customer: if something goes wrong a troubleshooter can be sent out at a few hours notice. Similarly, and particularly within Europe where distances are relatively low, joint ventures may be serviced by frequent short-term trips rather than by secondment (Koser and Salt, 1997).

The volume of business travel is enormous and growing. An analysis of data from 23 countries across 5 continents has revealed both the large numbers involved and a dramatic increase in flows through the late 1980s. Detailed breakdowns by destination have revealed the business-driven nature of moves; the spatial and temporal specificity of organisations' needs to place expertise overseas (Ford, 1992). For example, business visits to the UK increased by 90 per cent 1978-89, a process continuing in the 1990s (Rotheram and Salt, 1995). Unpublished data on the length of a business visit show the increasing importance of short-term travel, especially 1 to 2 day trips which account for $40-45$ per cent of all those made, and suggest that short-term trips are at least complements to, and may be increasingly substitutes for, longer-term relocation and migration. 


\section{The application of new information technologies}

The application of new information technologies will also tend to reduce the international migration of the highly skilled. Unlike the attributes of low-skilled migrant labour, which demand a physical presence in the performance of tasks, the main contribution of the highly skilled is knowledge. Knowledge can be transferred geographically in a number of ways not necessarily requiring a physical presence.

Modern satellite and fibre-optic communications, faxes and e-mail mean that specialists can be in almost instant touch with each other. Teleconferencing can already deal with routine business. The disadvantage of not being in the same room as the person with whom one is conferring is declining all the time, although the ultimate advantage of physical contact will never disappear in those sectors which traditionally place a premium on the quality of people and personality (O'Brien, 1992). However, new information technology enables a multiplication of possible meeting places, depending on the particular circumstances of the moment: to the modern PMT worker, office support and files are only a fax or modem away. It would be surprising if these facilities did not make some inroads into at least the growth of mobility among the highly skilled. At present, however, there is no research into the trade-off between the application of new technology for transferring knowledge, business travel and migration.

\section{Changing government perspectives}

Underlying the attitudes of most governments is the view that immigration of highly skilled workers is not only desirable but essential to protect investment. Although not under serious attack, this view is beginning to be questioned. Not surprisingly, answers are muted by a lack of research.

In the New World countries the majority of immigrants enter without any test of their skill levels. For those who do enter after tests, there is no guarantee that their accompanying dependants will have commensurate levels of skill. In Europe, too, the majority of immigrants in recent years have been the result of family reunion or asylum seeking (or illegal). In these circumstances "dilution" of national skill levels is unlikely to be substantially affected by attempts to attract skills. Again, sustained and internationally comparable research is lacking.

It is time also to look critically at the relationship between training programmes for high level skills and immigration. Here the problem is bedevilled by lead times. Training to high levels is a long and costly process, and the elasticity of supply is low, and manpower planning is a notoriously inexact science. Recruitment from overseas can also be time-consuming, especially when work permits are required. Yet with endemic high unemployment in most OECD countries, there can be no excuse for skill shortages.

Even the intra-company transfer system is not immune to challenge. A growing problem, not yet captured statistically, is the use by foreign-owned companies of corporate transferees on what is effectively a labour sub-contract basis. The process has recently come under public scrutiny mainly in the US, the UK, the Netherlands. In the UK and the Netherlands it seems to occur particularly in computing/systems and banking. It especially affects Third World-based companies which are bringing in foreign staff on secondment to install hard- and software systems often at low salaries. Because these firm pay generally lower wages than those in the highly developed economies, they are often able to undercut Western companies when tendering for contracts. The business literature indicates that cost savings of 20-30 per cent can easily be achieved by using Third World-based contractors. A further complication is that increasingly installation work can be done via satellite links, with only brief visits for checking purposes. 
This process of bringing in what are in effect sub-contract staff calls into question current arrangements for the international migration of the highly skilled. In effect, the corporate transfer system is being used by foreign companies to bring in staff to compete with indigenous labour and companies. The practice seems likely to grow unless host countries take steps to curb it, including a review of their policies towards corporate transfer. Rising education levels and populations in less developed countries are inevitably leading to larger bodies of high level skills there, with rates of remuneration that will make them increasingly competitive in the provision of expertise -- something that hitherto the developed economies could regard as their particular preserve. 


\section{BIBLIOGRAPHY}

AFTENPOSTEN (1997), 9 avril.

BERNSTEIN, J.H. and SHUVAL, J.T. (1996), "Occupational continuity and change among immigrant physicians from the former Soviet Union in Israel", International Migration, Vol. 33, No. 1, pp. 3-25.

BORJAS, G. (1990), Friends or Strangers, New York, Basic Books.

BOYLE, M., FINDLAY, A.M., LELIEVRE, E., PADDISON, R. (1994), "French investment and skill transfer in the United Kingdom", in W.T.S. Gould and A.M. Findlay (dir. publ.), Population Migration and the Changing World Order, London, John Wiley and Sons, pp. 47-65.

BROOKS, C., MURPHY, J., WILLIAMS, L.S. (1994), The role of skilled temporary residents in the Australian labour market, Bureau of Immigration and Population Research, Australie.

BUCHAN, J., SECCOMBE, I. and BALL, J. (1992), The international mobility of nurses: $a$ U.K. perspective, Institute of Manpower Studies, Report 230.

CHEN, S. (1996), "Migrant selectivity and returns to skills: the case of Taiwanese immigrants in the United States", International Migration, Vol. 33, No. 2, pp. 251-71.

CORNELIUS, W.A., MARTIN, P.L., HOLLIFIELD, J.F. (1994), Controlling Immigration: A Global Perspective, Standford, Stanford University Press.

DAS, M.S. (1971), “The 'brain drain' controversy in a comparative perspective”, International Review of Sociology, Vol. 1, No. 1, pp. 55-65.

DOLGIKH, E. (1995), "Determinants of migration potentials among Russian physicists", Studi Emigrazione, No. 117, pp. 144-58.

EMPLOYEE RELOCATION COUNCIL (1993), International Experience Index, Washington, DC.

FAKIOLAS, R. (1995), "The role of migration in raising the skill level of the labour force", Studi Emigrazione, No. 117, pp. 211-223.

FASSMAN, H., KOHLBACHER, J., REEGER, U. (1995), "Forgetting skills at borderline: foreign job-seekers on the Viennese labour market", Studi Emigrazione, No. 117, pp. 78-89.

FELLAT, F.M. (1995), “Les scientifiques marocains à l'étranger", Studi Emigrazione, No. 117, pp. 200-210. 
FINDLAY, A.M. (1990), "A migration channels approach to the study of high level manpower movements: a theoretical perspective", International Migration, No. 28(1), pp. 15-23.

FINDLAY, A.M. and GARRICK, L. (1990), "Scottish emigration in the 1980s: a migration channels approach to the study of skilled international migration", Transactions of the Institute of British Geographers, No. 15(2), pp. 177-92.

FINDLAY, A.M., LI, F.L.N., JOWETT, A.J., SKELDON, R. (1996), "Skilled international migration and the global city: A study of expatriates in Hong Kong", Transactions of the Institute of British Geographers, No. 21(1), pp. 49-61.

FONG, Pang Eng (1993), Régionalisation et flux de main-d'oeuvre en Asie du Pacifique, Paris, OCDE.

FORD, R. (1992), "Migration and stress among corporate employees", Thèse de doctorat inédite, Université de Londres.

GLASER, W.A. and HABERS, G.C. (1978), The Brain Drain: Emigration and Return, Pergamon, New York.

GOULD, W.T.S. (1988), "Skilled international labour migration: an introduction", Geoforum, No. 19(4), pp. 381-385.

HRYNIEWICZ, J. JALOWIECKI, B. and MYNC, A. (1992), The brain drain in Poland, Varsovie, Université de Varsovie, Institut européen de développement régional et local, Etudes régionales et locales 9.

KANJANAPAM, W. (1995), "The immigration of Asian professionals to the Unitied States: 1988-1990", International Migration Review, No. 29(1), pp. 7-32.

KEEBLE, D., BRYSON, J. and WOOD, P.A. (1991), "Small firms, business services growth and regional development in the UK: some empirical findings", Regional Studies, No. 25, pp. 439-58.

KING, R. and SHUTTLEWORTH, I. (1995), "The emigration and umployment of Irish graduates: The export of high-quality labour from the periphery of Europe", European Urban and Regional Studies, No. 2(1), pp. 21-40.

KPMG PEAT, MARWICK, McLINTOCK (1990), European Companies Entering into Partnerships, Londres.

KORCELLI, P. (1992), "International migration in Europe: Polish perspectives for the 1990s", International Migration Review, No. 26(2), pp. 292-304.

KOSER, K. and SALT, J. (1997), "The geography of international highly-skilled migration: a research review”, International Journal of Population Geography (à paraître).

KOUZMINOV, V. (1993), Brain drain issues in Europe: UNESCO project on intellectual migration, International Seminar: Skilled and Highly Skilled Migration, Latina, 28-29 octobre.

KRITZ, M. M. and CACES, F. (1992), Science and technology transfers and migration flows, in M.M. Kritz, L.L., Lim, H. Zlotnik, (dir. publ.), International Migration Systems: A Global Approach, Clarendon, Oxford, pp. 221-44. 
LAMARRA, N.F. (1992), Ressources humaines, développement et migrations des professions libérales en Amérique latine, 18p. Dixième séminaire de l'OIM sur la migration. Migration et développement. Genève, 15-17 septembre, Rapport No. 4.

LARSEN, K.A. (1993), Graduate Norwegian labour supply abroad, A survey-based approach. Rapport présenté au A2 COST Brain Drain workshop, Vienne, mai.

LEDENIOVA, L. (1995), “Attitude to emigration among University students in the former USSR", Studi Emigrazione, No. 117, pp. 189-99.

LEE, J. (1992), "Capital and labour mobility in Taiwan", in Taiwan: From Developing to Mature Economy, Boulder, Westview Press, pp. 305-56.

LI, F.L.N., FINDLAY, A.M., JOWETT, A.J., SKELDON, R. (1996), "Migrating to learn and learning to migrate: A study of the experiences and intentions of international student migrants", International Journal of Population Geography, No. 2(1), pp. 51-67.

LOGAN, I.B. (1992), The brain drain of professional, technical and kindred workers from developing countries: some lessons from the Africa-USA flow of professionals (1980-1989), 21 p., Dixième séminaire de l'OIM sur la migration, Migration et développement, Genève, 15-17 septembre, Rapport No. 3.

MONTANARI, A. (1995), “Skilled migrations from Italy”, Studi Emigrazione, No. 117, pp. 42-52.

MYERS, R.G. (1972), Education and Emigration: Study Abroad and the Migration of Human Resources, David McKay, New York.

O'BRIEN, R. (1992), Global financial integration: the end of geography, Londres, Printer for the Royal Institute of International Affairs, Chatham House papers.

ONG, P.M., CHENG, L., EVANS, L. (1992), "Migration of highly educated Asians and global dynamics", Asian and Pacific Migration Journal, 1(3-4), pp. 543-67.

PEARSON, R. (1992), Recruiting graduates in Europe for UK employment, Institute of Personnel Management, Londres.

OCDE (1993), SOPEMI, Tendances des migrations internationales, Rapport annuel, Paris.

RHODE, B. (1993a), Patterns of brain drain from the science sectors in Central and Eastern Europe after the collapse, Rapport établi pour la Commission des Communautés européennes, DG XII : Direction générale de la science, de la recherche et du développement.

RHODE, B. (1993b), "Brain drain, brain gain, brain waste: reflections on the emigration of highly educated and scientific personnel from Eastern Europe", in King, R. (ed.), The new geography of European migrations, Belhaven, Londres, pp. 228-245.

RODRIGUEZ, V. (1995), “Skilled migration in Spain”, Studi Emigrazione, No 117, pp. 54-65.

ROTHERAM, D. and SALT, J. (1995), Posted workers in Europe, Final Report to the Department of Employment. 
SALT, J. (1990), Foreign labour migration and the UK labour market: final report and dissemination of research findings, 210 p, Londres, University College.

SALT, J. (1992), "Migration processes among the highly skilled in Europe", International Migration Review, No. 26(98), pp. 484-505.

SALT, J. and FORD, R. (1993), "Skilled international migration in Europe: the shape of things to come?", in R. King (dir. publ.), Mass Migration in Europe, The Legacy and the Future, Londres, Belhaven, pp. 293-310.

SALT, J., MERVIN, J. and SHORTLAND, S. (1993), “The cost of international relocation", Relocation News, No. 26, pp. 4-7.

SALT, J. and SINGLETON, A. (1993), A comparison of the Labour Force Survey and Regulation 311/76 data sources on EU migrant worker stocks, Rapport final à EUROSTAT, Londres, UCL/MRU.

SEPSU (SCIENCE AND ENGINEERING POLICY STUDIES UNIT) (1987), "The migration of scientists and engineers to and from the UK", Policy Study No. 1.

SEPSU (SCIENCE AND ENGINEERING POLICY STUDIES UNIT) (1993), "The migration of scientists and engineers, 1984-1992", Policy Study No. 8.

TIKHONOV, V. (1993), "Migration potential within Russia's military-industrial complex", Studi Emigrazione, No. 117, pp. 128-43.

TODISCO, E. (1993), Intellectual movements and mobility of skills as alternative to the brain drain: geographic, social-economic and political elements affecting the intellectual and professional migration, International Seminar, Skilled and Highly Skilled Migration, Latina, 28-29 octobre.

VRANKEN, J. (1992), Migrants, guest workers and ethnic minorities, Document présenté à la conférence sur les migrations de masse en Europe, Vienne, 5-7 mars.

WERNER, H. (1993), "Mouvements migratoires dans la perspective du Marché unique européen", in Migrations internationales : le tournant, OCDE, Paris.

WOOD, P.A. (1994), An "expert labour" approach to business service change, Document présenté à l'Assemblée annuelle, Association of American Geographers, San Francisco, mars. 
Table 1. Japanese FDI (1951-91) and expatriate employment in Asia in 1992

\begin{tabular}{|c|c|c|c|c|}
\hline \multirow[t]{2}{*}{ Country } & \multicolumn{2}{|c|}{ FDI (1951-91) } & \multicolumn{2}{|c|}{ Japanese expatriates } \\
\hline & US\$ (millions) & $\%$ & Numbers & $\%$ \\
\hline Indonesia & 11547 & 24.3 & 3776 & 11.2 \\
\hline Hong Kong & 9849 & 20.7 & 6394 & 18.9 \\
\hline Singapore & 6554 & 13.8 & 5572 & 16.5 \\
\hline Thailand & 4422 & 9.3 & 6883 & 20.4 \\
\hline Rep. of Korea & 4138 & 8.7 & 1625 & 4.8 \\
\hline Malaysia & 3231 & 6.8 & 2777 & 8.2 \\
\hline China & 2823 & 5.9 & 2421 & 7.2 \\
\hline Chinese Taipei & 2731 & 5.7 & 1739 & 5.1 \\
\hline Philippines & 1580 & 3.3 & 1240 & 3.7 \\
\hline Rest of Asia & 644 & 1.4 & 1377 & 4.1 \\
\hline TOTAL & 47519 & 100.0 & 33804 & 100.0 \\
\hline
\end{tabular}

Sources: Far Eastern Economic Review and Japanese Ministry of Foreign Affairs

Table 2. NETHERLANDS: Foreign workers by profession, 1987 and 1995

\begin{tabular}{|c|c|c|c|c|c|}
\hline \multirow{3}{*}{ Profession } & \multirow{3}{*}{ Year } & \multicolumn{2}{|c|}{ Total } & \multicolumn{2}{|c|}{ Of which: } \\
\hline & & & & EU & non EU \\
\hline & & Thousands & $\%$ & Thousands & Thousands \\
\hline \multirow[t]{2}{*}{ Scientists, artists etc. } & 1987 & 35 & 19.9 & 23 & 12 \\
\hline & 1995 & 36 & 16.3 & 28 & 8 \\
\hline \multirow[t]{2}{*}{ Managerial, executives } & 1987 & 4 & 2.3 & 3 & 1 \\
\hline & 1995 & 6 & 2.7 & 4 & 2 \\
\hline \multirow[t]{2}{*}{ Administrative } & 1987 & 18 & 10.2 & 13 & 5 \\
\hline & 1995 & 20 & 9.0 & 13 & 7 \\
\hline \multirow[t]{2}{*}{ Others } & 1987 & 119 & 67.6 & 44 & 75 \\
\hline & 1995 & 159 & 71.9 & 51 & 108 \\
\hline \multirow[t]{2}{*}{ Total } & 1987 & 176 & 100.0 & 83 & 93 \\
\hline & 1995 & 221 & 100.0 & 96 & 125 \\
\hline
\end{tabular}

Source: Central Bureau of Statistics (CBS). 
Table 3. FRANCE: Socio-economic characteristics of foreign workers, 1990

\begin{tabular}{|c|c|c|c|c|c|c|c|c|c|}
\hline & \multicolumn{3}{|c|}{ Number } & \multicolumn{3}{|c|}{$\%$ row } & \multicolumn{3}{|c|}{$\%$ column } \\
\hline & EU & non-EU & Total & EU & non-EU & Total & $\mathrm{EU}$ & non-EU & Total \\
\hline Employers (10 workers and more) & 3864 & 2752 & 6616 & 58.4 & 41.6 & 100.0 & 0.6 & 0.3 & 0.4 \\
\hline $\begin{array}{l}\text { Liberal professions } \\
\text { Public admin., intellectual and artistic }\end{array}$ & 2772 & 3996 & 6768 & 41.0 & 59.0 & 100.0 & 0.4 & 0.4 & 0.4 \\
\hline professions & 12334 & 26966 & 39300 & 31.4 & 68.6 & 100.0 & 1.8 & 2.9 & 2.4 \\
\hline Managers of enterprises & 23272 & 22528 & 45800 & 50.8 & 49.2 & 100.0 & 3.4 & 2.4 & 2.8 \\
\hline public functions & 13469 & 24845 & 38314 & 35.2 & 64.8 & 100.0 & 2.0 & 2.6 & 2.4 \\
\hline commerce & 20444 & 23964 & 44408 & 46.0 & 54.0 & 100.0 & 3.0 & 2.5 & 2.7 \\
\hline Technicians & 8977 & 11608 & 20585 & 43.6 & 56.4 & 100.0 & 1.3 & 1.2 & 1.3 \\
\hline Total of above & 85132 & 116659 & 201791 & 42.2 & 57.8 & 100.0 & 12.6 & 12.4 & 12.5 \\
\hline Others & 590143 & 827651 & 1417794 & 41.6 & 58.4 & 100.0 & 87.4 & 87.6 & 87.5 \\
\hline
\end{tabular}

Source: Census, Table 17. 
Table 4. FRANCE: Inflows of permanent workers ${ }^{1}$ by professional status, 1990-1995

\begin{tabular}{|c|c|c|c|c|c|c|}
\hline & 1990 & 1991 & 1992 & 1993 & 1994 & $\overline{1995}$ \\
\hline & \multicolumn{6}{|c|}{ Numbers } \\
\hline $\begin{array}{l}\text { Professional, Managerial } \\
\text { and Technical }\end{array}$ & 6992 & 7166 & 5805 & 4562 & 5214 & 4611 \\
\hline Others & 15401 & 18441 & 36450 & 19826 & 13135 & 8495 \\
\hline \multirow[t]{2}{*}{ Total } & 22393 & 25607 & 42255 & 24388 & 18349 & 13106 \\
\hline & \multicolumn{6}{|c|}{ Percentages } \\
\hline $\begin{array}{l}\text { Professional, Managerial } \\
\text { and Technical }\end{array}$ & 31.2 & 28.0 & 13.7 & 18.7 & 28.4 & 35.2 \\
\hline Others & 68.8 & 72.0 & 86.3 & 81.3 & 71.6 & 64.8 \\
\hline Total & 100.0 & 100.0 & 100.0 & 100.0 & 100.0 & 100.0 \\
\hline
\end{tabular}

1. Including EU workers.

Source: Trends in International Migration, OECD, 1997.

Table 5. BELGIQUE: Socio-economic status of workers, 1983 and 1989

\begin{tabular}{|c|c|c|c|c|c|c|}
\hline \multicolumn{7}{|c|}{ Percentages } \\
\hline & \multicolumn{2}{|c|}{ Belgians } & \multicolumn{2}{|c|}{ Other EU } & \multicolumn{2}{|c|}{ Non-EU } \\
\hline & 1983 & 1989 & 1983 & 1989 & 1983 & 1989 \\
\hline White-collar & 46.5 & 51.2 & 30.4 & 30.8 & 21.8 & 21.2 \\
\hline Blue-collar & 38.6 & 32.5 & 56.1 & 53.2 & 69.3 & 64.8 \\
\hline Employers/self employed & 14.9 & 16.1 & 13.5 & 15.8 & 8.9 & 14.0 \\
\hline Total & 100.0 & 100.0 & 100.0 & 100.0 & 100.0 & 100.0 \\
\hline
\end{tabular}

Source: Vranken (1992). 
Table 6.

A. Inflows of professional/managerial and manual/clerical migrants ${ }^{1}$ to the United Kingdom 1980-94

\begin{tabular}{|c|c|c|c|c|c|c|}
\hline \multirow[t]{2}{*}{ YEAR } & \multicolumn{2}{|c|}{ Professional and managerial } & \multicolumn{2}{|c|}{ Manual and clerical } & \multicolumn{2}{|c|}{ Total } \\
\hline & Thousands & $\%$ & Thousands & $\%$ & Thousands & $\%$ \\
\hline 1980 & 44.5 & 57.9 & 32.4 & 42.1 & 76.9 & 100.0 \\
\hline 1981 & 45.2 & 65.8 & 23.5 & 34.2 & 68.7 & 100.0 \\
\hline 1982 & 43.7 & 53.6 & 37.8 & 46.4 & 81.5 & 100.0 \\
\hline 1983 & 55.3 & 60.6 & 36.0 & 39.4 & 91.3 & 100.0 \\
\hline 1984 & 58.8 & 65.0 & 31.7 & 35.0 & 90.5 & 100.0 \\
\hline 1985 & 65.4 & 66.9 & 32.4 & 33.1 & 97.8 & 100.0 \\
\hline 1986 & 76.2 & 62.3 & 46.1 & 37.7 & 122.3 & 100.0 \\
\hline 1987 & 63.1 & 56.5 & 48.6 & 43.5 & 111.7 & 100.0 \\
\hline 1988 & 66.7 & 60.4 & 43.8 & 39.6 & 110.5 & 100.0 \\
\hline 1989 & 75.5 & 60.7 & 48.8 & 39.3 & 124.3 & 100.0 \\
\hline 1990 & 93.1 & 63.7 & 53.2 & 36.3 & 146.3 & 100.0 \\
\hline 1991 & 80.5 & 58.9 & 56.1 & 41.1 & 136.6 & 100.0 \\
\hline 1992 & 62.6 & 58.5 & 44.4 & 41.5 & 107.0 & 100.0 \\
\hline 1993 & 64.2 & 60.3 & 42.3 & 39.7 & 106.5 & 100.0 \\
\hline 1994 & 81.7 & 59.2 & 56.3 & 40.8 & 138.0 & 100.0 \\
\hline
\end{tabular}

B. Outflows of professional/managerial and manual/clerical migrants ${ }^{1}$ to the United Kingdom 1980-1994

\begin{tabular}{|c|c|c|c|c|c|c|}
\hline \multirow[t]{2}{*}{ YEAR } & \multicolumn{2}{|c|}{ Professional and managerial } & \multicolumn{2}{|c|}{ Manual and clerical } & \multicolumn{2}{|c|}{ Total } \\
\hline & Thousands & $\%$ & Thousands & $\%$ & Thousands & $\%$ \\
\hline 1980 & 64.8 & 51.0 & 62.3 & 49.0 & 127.1 & 100.0 \\
\hline 1981 & 67.5 & 52.8 & 60.4 & 47.2 & 127.9 & 100.0 \\
\hline 1982 & 66.7 & 50.1 & 66.4 & 49.9 & 133.1 & 100.0 \\
\hline 1983 & 50.6 & 58.8 & 35.5 & 41.2 & 86.1 & 100.0 \\
\hline 1984 & 50.8 & 60.6 & 34.5 & 39.4 & 83.8 & 100.0 \\
\hline 1985 & 51.4 & 64.3 & 35.6 & 35.7 & 80.0 & 100.0 \\
\hline 1986 & 76.8 & 66.6 & 38.5 & 33.4 & 115.3 & 100.0 \\
\hline 1987 & 63.6 & 52.8 & 56.8 & 47.2 & 120.4 & 100.0 \\
\hline 1988 & 67.6 & 56.7 & 51.6 & 43.3 & 119.2 & 100.0 \\
\hline 1989 & 70.6 & 58.9 & 49.3 & 41.1 & 119.9 & 100.0 \\
\hline 1990 & 74.5 & 57.0 & 56.3 & 43.0 & 130.8 & 100.0 \\
\hline 1991 & 81.6 & 62.3 & 49.4 & 37.7 & 131.0 & 100.0 \\
\hline 1992 & 81.9 & 63.6 & 46.9 & 36.4 & 128.8 & 100.0 \\
\hline 1993 & 68.9 & 61.1 & 43.8 & 38.9 & 112.7 & 100.0 \\
\hline 1994 & 55.0 & 53.1 & 48.5 & 46.9 & 103.5 & 100.0 \\
\hline
\end{tabular}

1. Including British citizens. Professions refer to regular occupation prior to migration.

Source: International Passenger Survey. 
Table 7.

A. UNITED KINGDOM: Work permits and first permissions by occupation, 1985-1995 Thousands

\begin{tabular}{|c|c|c|c|c|c|c|c|c|c|c|c|}
\hline & 1985 & 1986 & 1987 & 1988 & 1989 & 1990 & 1991 & 1992 & 1993 & 1994 & 1995 \\
\hline General management & 37 & 37 & 49 & 54 & 39 & 69 & 71 & 113 & 108 & 136 & 211 \\
\hline Prof./manag. support & 809 & 817 & 715 & 847 & 1104 & 1398 & 1443 & 1598 & 2065 & 2705 & 3774 \\
\hline $\begin{array}{l}\text { Prof./manag. in education, } \\
\text { health and welfare }\end{array}$ & 125 & 132 & 139 & 234 & 207 & 381 & 374 & 374 & 545 & 519 & 503 \\
\hline Prof./manag. in science and tech. & 492 & 428 & 360 & 410 & 502 & 619 & 392 & 427 & 490 & 445 & 588 \\
\hline Other managerial & 133 & 166 & 70 & 133 & 124 & 72 & 34 & 43 & 29 & 15 & 29 \\
\hline All Prof./Managerial & 1596 & 1580 & 1333 & 1678 & 1976 & 2539 & 2314 & 2555 & 3237 & 3820 & 5105 \\
\hline Literary, Art, Sport & 6054 & 7381 & 8947 & 11177 & 11406 & 12451 & 11311 & 12568 & 11828 & 11213 & 12933 \\
\hline Clerical and related & 28 & 22 & 16 & 57 & 30 & 12 & 10 & 10 & 3 & 0 & 0 \\
\hline Catering, personal services & 41 & 32 & 227 & 285 & 350 & 330 & 263 & 315 & 62 & 92 & 74 \\
\hline Others & 101 & 178 & 110 & 57 & 119 & 281 & 725 & 172 & 118 & 134 & 376 \\
\hline TOTAL & 7820 & 9193 & 10633 & 13254 & 13881 & 15613 & 14623 & 15620 & 15248 & 15259 & 18488 \\
\hline \multicolumn{12}{|l|}{ LONG TERM (including TWES) } \\
\hline General management & 1338 & 1645 & 1945 & 2265 & 2020 & 2249 & 1650 & 1848 & 2252 & 2328 & 2683 \\
\hline Prof./manag. support & 3321 & 3654 & 3628 & 4656 & 6146 & 6474 & 4984 & 4271 & 3546 & 3566 & 4277 \\
\hline $\begin{array}{l}\text { Prof./manag. in education, } \\
\text { health and welfare }\end{array}$ & 808 & 791 & 804 & 1348 & 1685 & 3794 & 2539 & 2916 & 3448 & 3638 & 2397 \\
\hline Prof./manag. in science and tech. & 1775 & 1161 & 1501 & 2291 & 3040 & 2677 & 2080 & 2630 & 2924 & 3010 & 3888 \\
\hline Other managerial & 273 & 352 & 292 & 229 & 265 & 162 & 188 & 124 & 57 & 37 & 21 \\
\hline All Prof./Managerial & 7515 & 8103 & 8170 & 10789 & 13156 & 15356 & 11444 & 11789 & 12227 & 12579 & 13266 \\
\hline Literary, Art, Sport & 692 & 770 & 713 & 1175 & 1085 & 1359 & 1387 & 1440 & 1332 & 1341 & 1644 \\
\hline Clerical and related & 34 & 27 & 33 & 84 & 75 & 15 & 17 & 14 & 4 & 1 & 1 \\
\hline Catering, personal services & 321 & 396 & 422 & 517 & 812 & 810 & 844 & 746 & 255 & 198 & 371 \\
\hline Others & 192 & 199 & 172 & 154 & 721 & 1394 & 1667 & 442 & 262 & 714 & 1695 \\
\hline TOTAL & 8754 & 9495 & 9715 & 12719 & 15849 & 19014 & 15356 & 14431 & 14080 & 14833 & 16977 \\
\hline
\end{tabular}

B. United Kingdom: Work permits and first permissions by occupation, 1985-1995

Percentages

\begin{tabular}{|c|c|c|c|c|c|c|c|c|c|c|c|}
\hline \multicolumn{12}{|l|}{ SHORT TERM (including TWES) } \\
\hline & 1985 & 1986 & 1987 & 1988 & 1989 & 1990 & 1991 & 1992 & 1993 & 1994 & 1995 \\
\hline General management & 0.5 & 0.4 & 0.5 & 0.4 & 0.3 & 0.4 & 0.5 & 0.7 & 0.7 & 0.9 & 1.1 \\
\hline Prof./manag. support & 10.3 & 8.9 & 6.7 & 6.4 & 8.0 & 9.0 & 9.9 & 10.2 & 13.5 & 17.7 & 20.4 \\
\hline $\begin{array}{l}\text { Prof./manag. in education, } \\
\text { health and welfare }\end{array}$ & 1.6 & 1.4 & 1.3 & 1.8 & 1.5 & 24 & 26 & 2.4 & 36 & 34 & 27 \\
\hline Prof./manag. in science and tech. & 6.3 & 4.7 & 3.4 & 3.1 & 3.6 & 4.0 & 2.7 & 2.7 & 3.2 & 2.9 & 3.2 \\
\hline Other managerial & 1.7 & 1.8 & 0.7 & 1.0 & 0.9 & 0.5 & 0.2 & 0.3 & 0.2 & 0.1 & 0.2 \\
\hline All Prof./Managerial & 20.4 & 17.2 & 12.5 & 12.7 & 14.2 & 16.3 & 15.8 & 16.4 & 21.2 & 25.0 & 27.6 \\
\hline Literary, Art, Sport & 77.4 & 80.3 & 84.1 & 84.3 & 82.2 & 79.7 & 77.4 & 80.5 & 77.6 & 73.5 & 70.0 \\
\hline Clerical and related & 0.4 & 0.2 & 0.2 & 0.4 & 0.2 & 0.1 & 0.1 & 0.1 & 0.0 & 0.0 & 0.0 \\
\hline Catering, personal services & 0.5 & 0.3 & 2.1 & 2.2 & 2.5 & 2.1 & 1.8 & 2.0 & 0.4 & 0.6 & 0.4 \\
\hline Others & 1.3 & 1.9 & 1.0 & 0.4 & 0.9 & 1.8 & 5.0 & 1.1 & 0.8 & 0.9 & 2.0 \\
\hline TOTAL & 100.0 & 100.0 & 100.0 & 100.0 & 100.0 & 100.0 & 100.0 & 100.0 & 100.0 & 100.0 & 100.0 \\
\hline \multicolumn{12}{|l|}{ LONG TERM (including TWES) } \\
\hline General management & 15.3 & 17.3 & 20.0 & 17.8 & 12.7 & 11.8 & 10.7 & 12.8 & 16.0 & 15.7 & 15.8 \\
\hline Prof./manag. support & 37.9 & 38.5 & 37.3 & 36.6 & 38.8 & 34.0 & 32.5 & 29.6 & 25.2 & 24.0 & 25.2 \\
\hline $\begin{array}{l}\text { Prof./manag. in education, } \\
\text { health and welfare }\end{array}$ & 9.2 & 8.3 & 8.3 & 10.6 & 10.6 & 20.0 & 16.5 & 20.2 & 24.5 & 24.5 & 14.1 \\
\hline Prof./manag. in science and tech. & 20.3 & 12.2 & 15.5 & 18.0 & 19.2 & 14.1 & 13.5 & 18.2 & 20.8 & 20.3 & 22.9 \\
\hline Other managerial & 3.1 & 3.7 & 3.0 & 1.8 & 1.7 & 0.9 & 1.2 & 0.9 & 0.4 & 0.2 & 0.1 \\
\hline All Prof./Managerial & 85.8 & 85.3 & 84.1 & 84.8 & 83.0 & 80.8 & 74.5 & 81.7 & 86.8 & 84.8 & 78.1 \\
\hline Literary, Art, Sport & 7.9 & 8.1 & 7.3 & 9.2 & 6.8 & 7.1 & 9.0 & 10.0 & 9.5 & 9.0 & 9.7 \\
\hline Clerical and related & 0.4 & 0.3 & 0.3 & 0.7 & 0.5 & 0.1 & 0.1 & 0.1 & 0.0 & 0.0 & 0.0 \\
\hline Catering, personal services & 3.7 & 4.2 & 4.3 & 4.1 & 5.1 & 4.3 & 5.5 & 5.2 & 1.8 & 1.3 & 2.2 \\
\hline Others & 2.2 & 2.1 & 1.8 & 1.2 & 4.5 & 7.3 & 10.9 & 3.1 & 1.9 & 4.8 & 10.0 \\
\hline TOTAL & 100.0 & 100.0 & 100.0 & 100.0 & 100.0 & 100.0 & 100.0 & 100.0 & 100.0 & 100.0 & 100.0 \\
\hline
\end{tabular}

Source: Department of Employment (unpublished). 
Table 8. UNITED KINGDOM: Socio-economic groups by profession and sex, 1995

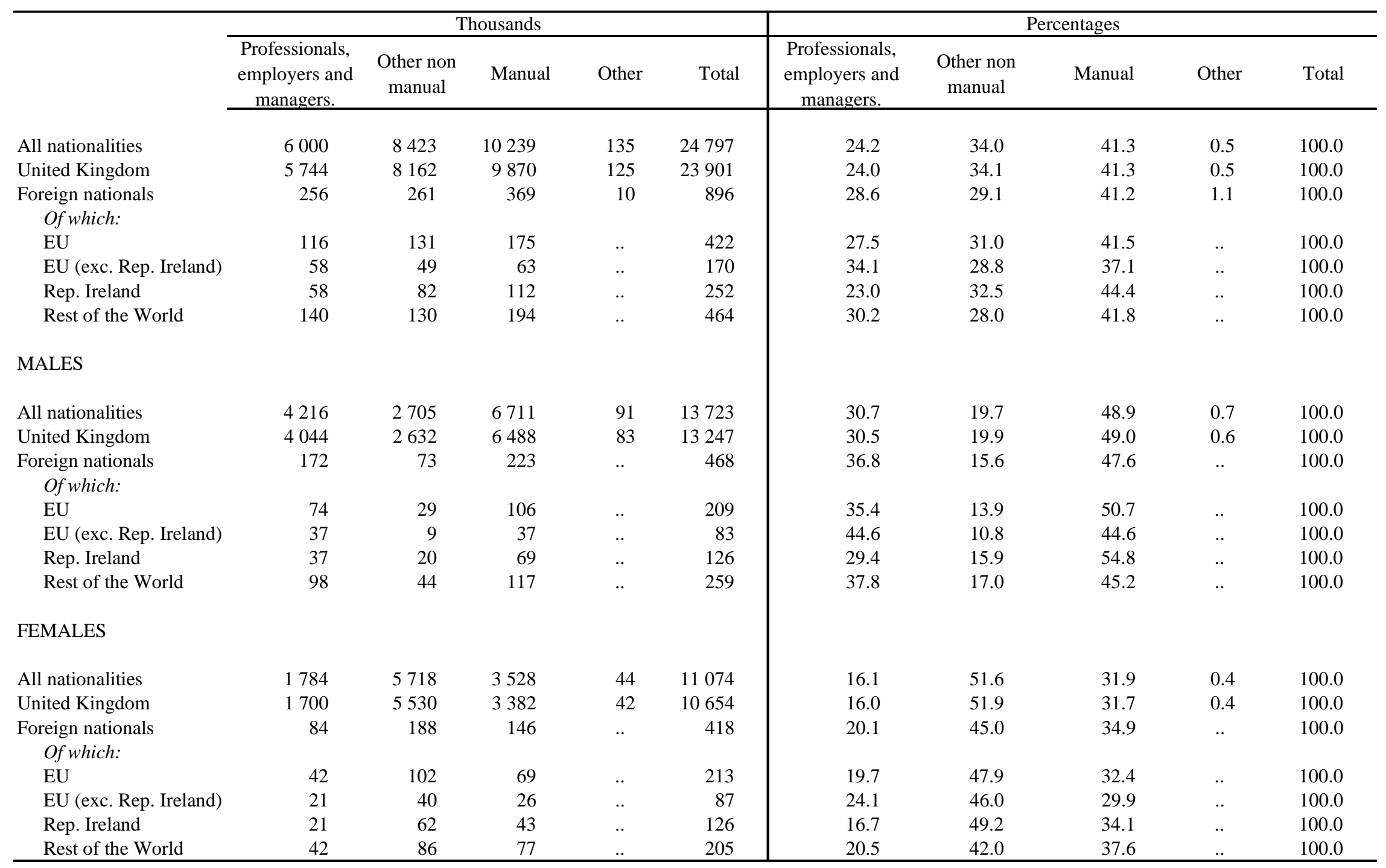

Source: Labour Force Survey. 
Table 9. Immigration to Norway, 1990-1993

\begin{tabular}{lcc|cc|cc|cc}
\hline & \multicolumn{2}{c}{1990} & \multicolumn{2}{c|}{1991} & \multicolumn{2}{c|}{1992} & \multicolumn{2}{c}{1993} \\
\cline { 2 - 10 } & Number & $\%$ & Number & $\%$ & Number & $\%$ & Number & $\%$ \\
\cline { 2 - 10 } Specialists & 719 & 65.9 & 707 & 61.9 & 746 & 61.6 & 739 & 59.5 \\
Total workers & 1091 & 100.0 & 1143 & 100.0 & 1212 & 100.0 & 1243 & 100.0 \\
\hline
\end{tabular}

Table 10. PORTUGAL: Stock of foreign workers with a valid residence permit, 1989-1991

\begin{tabular}{|c|c|c|c|c|c|c|c|}
\hline & \multicolumn{3}{|c|}{ Numbers } & \multicolumn{3}{|c|}{$\%$} & \multirow{2}{*}{$\begin{array}{l}\text { Change } \\
1989-91\end{array}$} \\
\hline & 1989 & 1990 & 1991 & 1989 & 1990 & 1991 & \\
\hline Professional workers & 11394 & 12743 & 13927 & 23.4 & 24.6 & 25.3 & 22.2 \\
\hline Managerial workers & 3065 & 3465 & 3839 & 6.3 & 6.7 & 7.0 & 25.3 \\
\hline Administrative workers & 2426 & 2592 & 2682 & 5.0 & 5.0 & 4.9 & 10.6 \\
\hline Other & 31772 & 32981 & 34491 & 65.3 & 63.7 & 62.8 & 8.6 \\
\hline Total & 48657 & 51781 & 54939 & 100.0 & 100.0 & 100.0 & \\
\hline
\end{tabular}

Source: Ministry of the Interior. 
Table 11. SPAIN: Work permits issued to highly skilled workers, 1987-1994

\begin{tabular}{|c|c|c|c|c|c|c|c|c|c|c|c|c|c|c|c|c|}
\hline & \multicolumn{2}{|c|}{1987} & \multicolumn{2}{|c|}{1988} & \multicolumn{2}{|c|}{1989} & \multicolumn{2}{|c|}{1990} & \multicolumn{2}{|c|}{1991} & \multicolumn{2}{|c|}{1992} & \multicolumn{2}{|c|}{1993} & \multicolumn{2}{|c|}{1994} \\
\hline & Number & Percent & Number & Percent & Number & Percent & Number & Percent & Number & Percent & Number & Percent & Number & Percent & Number & Percent \\
\hline Professional and technical workers & 9934 & 19.0 & 9449 & 20.7 & 11148 & 23.3 & 13069 & 25.5 & 19851 & 15.7 & 11524 & 12.1 & 9273 & 9.9 & 6639 & 7.5 \\
\hline Managerial workers & 3002 & 5.7 & 2814 & 4.8 & 2273 & 4.7 & 3261 & 5.5 & 3261 & 2.6 & 1572 & 1.7 & 1403 & 1.5 & 1107 & 1.2 \\
\hline Total of the above two categories & 12936 & 24.7 & 12263 & 25.5 & 13421 & 28.0 & 16330 & 31.0 & 23112 & 18.3 & 13096 & 13.8 & 10676 & 11.4 & 7746 & 8.7 \\
\hline Total & 52258 & 100.0 & 45539 & 100.0 & 47943 & 100.0 & 51210 & 100.0 & 126140 & 100.0 & 94955 & 100.0 & 93696 & 100.0 & 88620 & 100.0 \\
\hline
\end{tabular}

Source: Estadistica de Permisos de Trabajo a Extranjeros (1994), Ministry of Labour and Social Affairs.

Table 12. Workers in the United Kingdom who were working outside the UK one year previously for the same or a different employer, $1985-1995$ Thousands and percentages

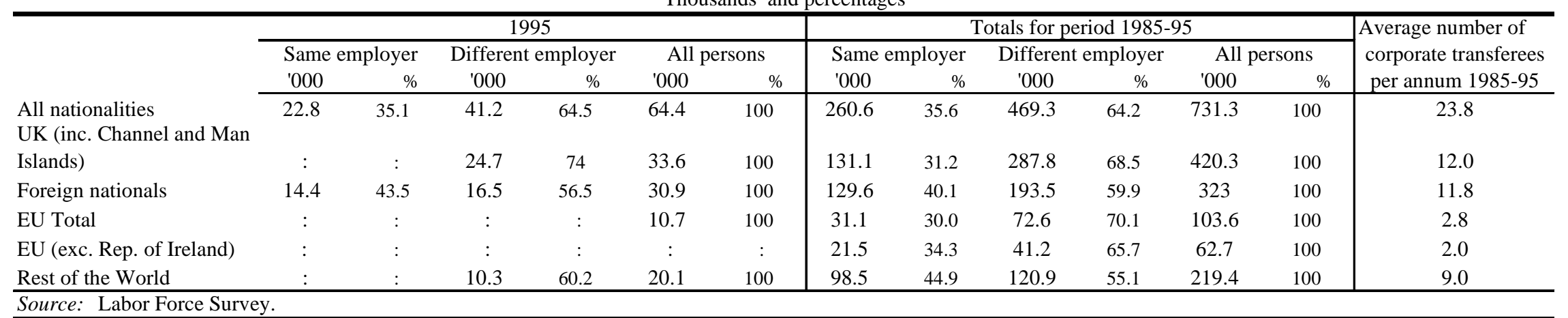




\begin{tabular}{|c|c|c|c|c|c|c|c|}
\hline & 1981 & 1985 & 1990 & 1991 & 1992 & 1993 & 1994 \\
\hline Intra-company transferees (L1) & 38595 & 65349 & 63180 & 70505 & 75315 & 82606 & 98189 \\
\hline Spouses and children of above (L2) & 26449 & 41533 & 39375 & 42529 & 45464 & 49537 & 56048 \\
\hline Total (L1+L2) & 65044 & 106882 & 102555 & 113034 & 120779 & 132143 & 154237 \\
\hline
\end{tabular}

Table 14. UNITED STATES: Intra-company transferees by origin, 1994

\begin{tabular}{|c|c|c|}
\hline & Number & $\%$ \\
\hline Europe & 45779 & 46.6 \\
\hline \multicolumn{3}{|l|}{ Of which: } \\
\hline United Kingdom & 17405 & 17.7 \\
\hline France & 5626 & 5.7 \\
\hline Germany & 6309 & 6.4 \\
\hline Asia & 28707 & 29.2 \\
\hline \multicolumn{3}{|l|}{ Of which: } \\
\hline Japan & 17930 & 18.3 \\
\hline China (including Chinese Taipei) & 4319 & 4.4 \\
\hline Africa & 811 & 0.8 \\
\hline North America & 10534 & 10.7 \\
\hline \multicolumn{3}{|l|}{ Of which: } \\
\hline Canada & 6482 & 6.6 \\
\hline Mexico & 2632 & 2.7 \\
\hline South America & 8066 & 8.2 \\
\hline \multicolumn{3}{|l|}{ Of which: } \\
\hline Brazil & 3283 & 3.3 \\
\hline Venezuela & 1543 & 1.6 \\
\hline Argentina & 1242 & 1.3 \\
\hline Oceania & 4046 & 4.1 \\
\hline \multicolumn{3}{|l|}{ Of which: } \\
\hline Australia & 3267 & 3.3 \\
\hline Total & 98189 & 100.0 \\
\hline
\end{tabular}


Table 15. Number of foreign students enrolled at the tertiary level in selected OECD countries

\begin{tabular}{|c|c|c|c|c|c|c|c|c|}
\hline & 1980 & 1985 & $\begin{array}{c}1980-85 \\
\% \text { change }\end{array}$ & 1988 & 1989 & 1990 & 1991 & 1992 \\
\hline Australia & 8777 & 16075 & 83.1 & 18207 & 25447 & 28993 & 34408 & 39490 \\
\hline Austria & 11848 & 15388 & 29.9 & 16580 & 17306 & 18434 & 20199 & 21980 \\
\hline Belgium & 12875 & 24761 & 92.3 & 23966 & 33335 & .. & .. & .. \\
\hline Canada & 28443 & 29496 & 3.7 & 28622 & 32144 & 35187 & 37269 & 37478 \\
\hline Denmark & 3035 & 3167 & 4.3 & 6609 & 6864 & 6728 & 7008 & 7637 \\
\hline Finland & 610 & 979 & 60.5 & 1230 & 1356 & 1617 & 1899 & 2182 \\
\hline France & 110763 & 131979 & 19.2 & 125574 & 143640 & 136015 & 139963 & 138477 \\
\hline \multicolumn{9}{|l|}{ Germany: } \\
\hline FRG & 61841 & 79354 & 28.3 & 91926 & 97985 & 107005 & 116474 & .. \\
\hline GDR & 7106 & 9231 & 29.9 & 13343 & .. & .. & .. & .. \\
\hline Greece & 7673 & 6683 & -12.9 & .. & 1456 & .. & .. & .. \\
\hline Ireland & 2845 & 2606 & -8.4 & 2889 & 3094 & 3282 & 3753 & .. \\
\hline Italy & 29447 & 26286 & -10.7 & 21411 & 20199 & 21788 & 20513 & 20811 \\
\hline Japan & 6543 & 12442 & 90.2 & 20373 & 23816 & .. & 45066 & .. \\
\hline Netherlands & 4128 & 5705 & 38.2 & 9224 & .. & 8876 & 10439 & 11389 \\
\hline New Zealand & 2464 & 2618 & 6.3 & 3678 & 3595 & 3229 & 2926 & 3999 \\
\hline Norway & 1114 & .. & .. & .. & .. & 6907 & 7757 & .. \\
\hline Portugal & 1318 & 2047 & 55.3 & .. & 3608 & 3773 & .. &.. \\
\hline Spain & 10997 & .. & .. & 13839 & 11051 & .. & .. & .. \\
\hline Sweden & .. & 10401 & .. & 10650 & .. & .. & .. & .. \\
\hline Switzerland & 14716 & 17396 & 18.2 & 14462 & 20914 & 22621 & 24412 & 24844 \\
\hline Turkey & 6655 & 7021 & 5.5 & 7502 & 7904 & 7661 & 7548 & 7850 \\
\hline United Kingdom & 56003 & 53694 & -4.1 & 63223 & 70717 & 80183 & 88141 & 95594 \\
\hline United States & 311882 & 343780 & 10.2 & 366354 &.. & 407529 & 419585 & 438618 \\
\hline
\end{tabular}

1. Or 1985 and latest available year.

2. Percentage change 1980-1991.

Source: UNESCO. 
Table 16. Number of foreign students enrolled in selected OECD countries by continent of origine, last available year

\begin{tabular}{|c|c|c|c|c|c|c|c|c|c|}
\hline & Year & Total & $\begin{array}{c}\text { Africa } \\
\%\end{array}$ & $\begin{array}{c}\text { North America } \\
\%\end{array}$ & $\begin{array}{c}\text { South } \\
\text { America } \\
\%\end{array}$ & $\begin{array}{c}\text { Asia } \\
\%\end{array}$ & $\begin{array}{c}\text { Europe } \\
\%\end{array}$ & $\begin{array}{c}\text { Former } \\
\text { USSR } \\
\%\end{array}$ & $\begin{array}{c}\text { Oceania } \\
\%\end{array}$ \\
\hline Australia & 1993 & 56480 & 1.4 & 1.9 & 0.1 & 55.6 & 29.8 & - & 11.1 \\
\hline Austria & 1993 & 23911 & 4.2 & 2.6 & 1.3 & 20.1 & 70.3 & - & 0.2 \\
\hline Belgium & 1990 & 27378 & 34.0 & 1.9 & 2.5 & 10.1 & 49.3 & - & 0.0 \\
\hline Canada & 1993 & 35451 & 16.5 & 12.9 & 2.6 & 48.0 & 17.4 & - & 1.0 \\
\hline Denmark & 1992 & 4946 & 2.8 & 5.8 & 1.6 & 30.5 & 58.6 & 0.3 & 0.3 \\
\hline Finland & 1993 & 2348 & 12.9 & 6.4 & 1.8 & 30.4 & 45.3 & - & 0.5 \\
\hline France & 1993 & 139562 & 52.8 & 4.1 & 3.0 & 14.1 & 25.6 & - & 0.1 \\
\hline Germany & 1991 & 116474 & 6.8 & 4.7 & 2.9 & 43.0 & 40.5 & 0.6 & 0.2 \\
\hline Ireland & 1991 & 3753 & 4.3 & 19.7 & 0.3 & 25.7 & 49.2 & - & 0.8 \\
\hline Italy & 1993 & 22618 & 12.0 & 3.8 & 4.6 & 16.3 & 62.6 & - & 0.6 \\
\hline Japan & 1991 & 45066 & 0.7 & 3.3 & 1.3 & 92.2 & 1.8 & 0.1 & 0.6 \\
\hline Netherlands & 1992 & 11389 & 10.0 & 3.6 & 13.1 & 25.6 & 46.7 & 0.4 & 0.6 \\
\hline New Zealand & 1993 & 4489 & 1.6 & 3.6 & 0.7 & 42.4 & 4.1 & - & 44.5 \\
\hline Norway & 1993 & 10021 & 11.3 & 9.0 & 3.0 & 35.7 & 40.1 & 0.5 & 0.3 \\
\hline Portugal & 1989 & 3608 & 61.6 & 3.8 & 24.2 & 0.5 & 9.6 & - & 0.3 \\
\hline Spain & 1992 & 12578 & 13.8 & 10.8 & 27.5 & 7.9 & 39.5 & 0.2 & 0.4 \\
\hline Sweden & 1988 & 10650 & 3.3 & 5.0 & 4.1 & 21.3 & 61.2 & 0.4 & 0.2 \\
\hline Switzerland & 1993 & 23159 & 5.9 & 3.2 & 3.6 & 7.9 & 79.2 & - & 0.2 \\
\hline Turkey & 1993 & 13554 & 4.8 & 0.3 & - & 76.7 & 18.1 & - & 0.1 \\
\hline United Kingdom & 1992 & 95594 & 8.9 & 8.3 & 1.5 & 37.8 & 42.2 & 0.1 & 0.9 \\
\hline United States & 1993 & 449749 & 4.6 & 10.6 & 4.6 & 65.4 & 13.3 & 0.7 & 0.9 \\
\hline Total & & 1112778 & 12.5 & 7.3 & 3.6 & 47.3 & 26.3 & 0.4 & 1.3 \\
\hline
\end{tabular}

